Florida International University

FIU Digital Commons

$4-1-2008$

\title{
The relationship of immigrant status to perceptions of reading and reading literacy among young black students : a test of the cultural-ecological theory of school performance
}

Shelby G. Gilbert

Florida International University

Follow this and additional works at: https://digitalcommons.fiu.edu/etd

Part of the Curriculum and Instruction Commons

\section{Recommended Citation}

Gilbert, Shelby G., "The relationship of immigrant status to perceptions of reading and reading literacy among young black students : a test of the cultural-ecological theory of school performance" (2008). FIU Electronic Theses and Dissertations. 3937.

https://digitalcommons.fiu.edu/etd/3937

This work is brought to you for free and open access by the University Graduate School at FIU Digital Commons. It has been accepted for inclusion in FIU Electronic Theses and Dissertations by an authorized administrator of FIU Digital Commons. For more information, please contact dcc@fiu.edu. 
FLORIDA INTERNATIONAL UNIVERSITY

Miami, Florida

THE RELATIONSHIP OF IMMIGRANT STATUS TO PERCEPTIONS OF READING AND READING LITERACY AMONG YOUNG BLACK STUDENTS: A TEST OF THE CULTURAL-ECOLOGICAL THEORY OF SCHOOL PERFORMANCE

A dissertation submitted in partial fulfillment of the requirements for the degree of DOCTOR OF EDUCATION in CURRICULUM AND INSTRUCTION by

Shelby G. Gilbert 
To: Dean Luis Mirón

College of Education

This dissertation, written by Shelby G. Gilbert, and entitled The Relationship of Immigrant Status to Perceptions of Reading and Reading Literacy among Young Black Students: A Test of the Cultural-Ecological Theory of School Performance, having been approved in respect to style and intellectual content, is referred to you for judgment.

We have read this dissertation and recommend that it be approved.

Linda Spears-Bunton

Robert V. Farrell

Lynne Miller

Marvin P. Dawkins

Kingsley Banya, Major Professor

Date of Defense: April 1, 2008

The dissertation of Shelby G. Gilbert is approved.

Dean Luis Mirón

College of Education

Dean George Walker

University Graduate School

Florida International University, 2008 
(C) Copyright 2008 by Shelby G. Gilbert

All rights reserved. 


\section{DEDICATION}

"Until the lions have their own historians, the tales of the hunt will always glorify the

$$
\text { hunter" }
$$

-African Proverb

I dedicate this dissertation to the memory of my parents and all those who came before me whose tales were never told 


\section{ACKNOWLEDGMENTS}

I would like to express my sincere appreciation for the love and support that I have received from my brothers, Berkeley and Stephen, and my other family members during the process of writing this dissertation. I would like to thank Dr. Lafleur Small and Simone O'Bryan for their many years of friendship, and for nudging me along as we all embarked on this journey. Also, a very special note of appreciation goes to Alex.

I would also like to thank members of my surrogate family-my FIU familywho have influenced my life during the past few years. Leanne, Claudia, Laura and Alda in particular, have become the sisters I never had as we all worked through this academic process together. Of course, there are faculty members who have been instrumental in getting me through this journey. Dr. Isadore Newman and Dr. Linda Bliss, thank you for your tireless dedication to graduate students and your commitment to helping us produce quality work. I hope to someday make you proud. Dr. Leonard Bliss, thank you for introducing me to the joy of statistics. Thank you, Dr. Paulette Johnson, for the invaluable experience I gained while working with you in the Statistical Consulting Office. I would like to thank Jeffrey Knapp, Director of The Academy for the Art of Teaching, for many years of moral support. I would also like to thank the Florida International University Graduate School for awarding me the 2007 Dissertation Year Fellowship.

Finally, I would like to thank the members of my committee for their neverending guidance and support. Thank you, Dr. Lynne Miller, for your insight. Dr. Linda Spears-Bunton, your eloquent words of inspiration have meant so much to me. Dr. Robert Farrell, you have exposed me to so much over the past few years. Thank you 
especially for inspiring me to think about the impact of my ecological footprint on society. I still have a way to go, but I'm getting there. Dr. Marvin Dawkins, I have now known you for over ten years, and you have been most instrumental in helping me to develop my academic goals. Most importantly, I would like to thank my major professor, Dr. Kingsley Banya, for your endless support while I have been here at FIU. Your guidance has paved the way for me come to the end of this journey. Although the road has sometimes been bumpy along the way, I can now see the light at the end of the tunnel. I hope you were as proud to have me as a student as I was as proud to have you as my major professor. 


\begin{abstract}
OF THE DISSERTATION
THE RELATIONSHIP OF IMMIGRANT STATUS TO PERCEPTIONS OF READING

AND READING LITERACY AMONG YOUNG BLACK STUDENTS: A TEST OF

THE CULTURAL-ECOLOGICAL THEORY OF SCHOOL PERFORMANCE
\end{abstract}

by

Shelby G. Gilbert

Florida International University, 2008

Miami, Florida

Professor Kingsley Banya, Major Professor

This study tests Ogbu and Simons' Cultural-Ecological Theory of School Performance using data from the Progress in International Reading Literacy Study of 2001 (PIRLS), a large-scale international survey and reading assessment involving fourth grade students from 35 countries, including the United States. This theory argues that Black immigrant students outperform their non-immigrant counterparts, academically, and that achievement differences are attributed to stronger educational commitment in Black immigrant families. Four hypotheses are formulated to test this theory: Black immigrant students have (a) more receptive attitudes toward reading; (b) a more positive reading self-concept; and (c) a higher level of reading literacy. Furthermore, (d) the relationship of immigrant status to reading perceptions and literacy persists after including selected predictors. These hypotheses are tested separately for girls and boys, while also examining immigrant students' generational status (i.e., foreign-born or second-generation). 
PIRLS data from a subset of Black students $(\mathrm{N}=525)$ in the larger U.S. sample of 3,763 are analyzed to test the hypotheses, using analysis of variance, correlation and multiple regression techniques. Findings reveal that hypotheses $a$ and $b$ are not confirmed (contradicting the Cultural-Ecological Theory) and $\mathrm{c}$ and $\mathrm{d}$ are partially supported (lending partial support to the theory). Specifically, immigrant and non-immigrant students did not differ in attitudes toward reading or reading self-concept; secondgeneration immigrant boys outperformed both non-immigrant and foreign-born immigrant boys in reading literacy, but no differences were found among girls; and, while being second-generation immigrant had a relatively stronger relationship to reading literacy for boys, among girls, selected socio-cultural predictors, number of books in the home and length of U.S. residence, had relatively stronger relationship to reading selfconcept than did immigrant status. This study, therefore, indicates that future research employing the Cultural-Ecological Theory should: (a) take gender and generational status into account (b) identify additional socio-cultural predictors of Black children's academic perceptions and performance; and (c) continue to build on this body of evidence-based knowledge to better inform educational policy and school personnel in addressing needs of all children. 


\section{TABLE OF CONTENTS}

CHAPTER

PAGE

I. INTRODUCTION

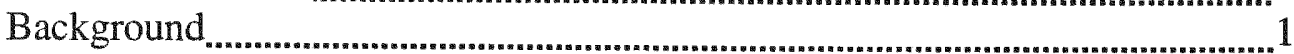

Purpose of the Study ................................................................................................. 3

General Statement of the Problem ........................................................................... 5

Research Questions, ........................................................................................................... 7

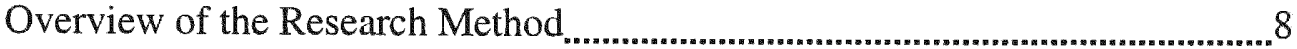

Social Significance of the Study......................................................................................

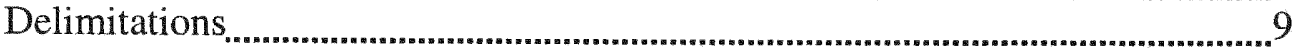

Definition of Key Terms ......................................................................................... 10

Chapter Summary and Overview of Remaining Chapters..................................112

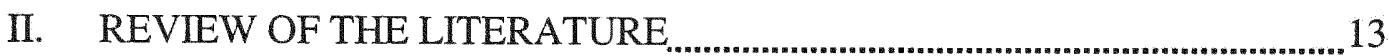

Overview of the State of Education for Black Students ......................................13

John Ogbu and the Classification Schema of Minorities.....................................16

Ogbu and Simons' Cultural-Ecological Theory of School Performance............21

Segmented Assimilation Theory............................................................................... 36

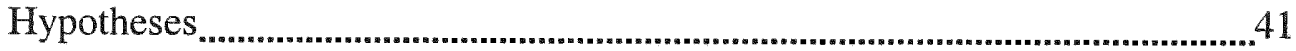

Summary ...........................................................................................................

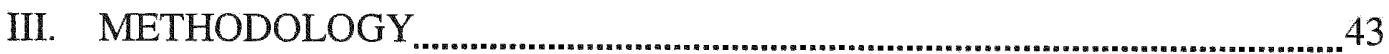

Research Design ...................................................................................................4

Population and Sample Selection ......................................................................44

Data Collection Procedures......................................................................................4

Measurement of Variables ..................................................................................4

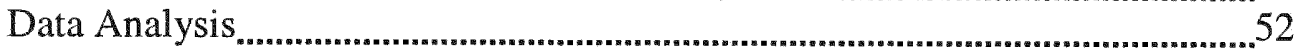

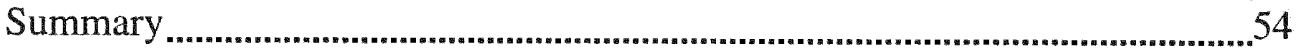

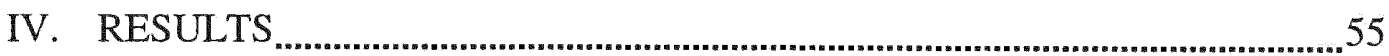

Description of the Sample

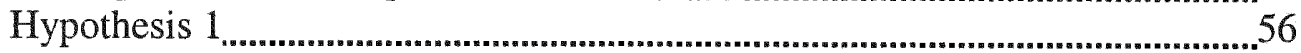

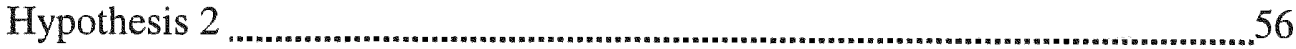

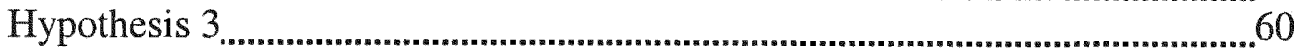

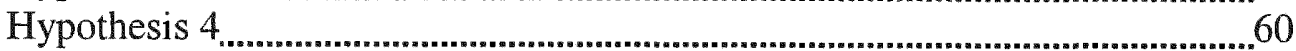

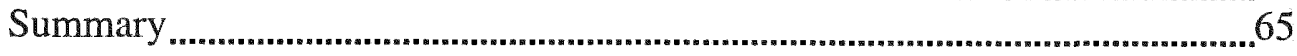

V. DISCUSSION AND CONCLUSIONS _.......................................................... 71

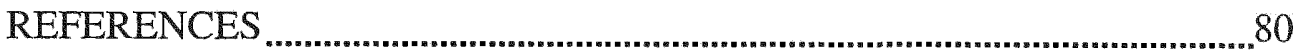


APPENDICES

VITA 


\section{LIST OF TABLES}

\section{TABLE}

PAGE

1. Description of the Sample 57

2. Mean Statistics for Student Attitudes Toward Reading (SATR) by Sex and Immigrant status

3. Mean Statistics for Student Reading Self-Concept (SRSC) by Sex and Immigrant status

4. Mean Statistics for Reading Literacy Achievement by Sex and Immigrant Status

5. Intercorrelations among Variables by Sex 67

6. OLS Coefficients for Regression of Student Attitudes Toward Reading (SATR) on Immigrant Status, Background/Socioeconomic Status (SES), and Behavioral/Cultural Characteristics by Sex.

7. OLS Coefficients for Regression of Student Reading Self-Concept (SRSC) on Immigrant Status, Background/Socioeconomic Status (SES), and Behavioral/Cultural Characteristics by Sex

8. OLS Coefficients for Regression of Reading Achievement on Immigrant Status, Background/Socioeconomic Status (SES), and Behavioral/Cultural Characteristics by Sex 


\section{CHAPTER I}

\section{INTRODUCTION}

This dissertation is a study of Black students' immigrant status, socio-cultural background and reading literacy in the United States. The study is based on secondary analysis of data from the Progress in International Reading Literacy Study of 2001 (PIRLS), a large, international reading assessment test that was administered to students in 35 countries, including the U.S., in grades equivalent to the United States' fourth grade. This first chapter of the dissertation presents the background of the study, states the purpose and general problem, specifies its major research questions and social significance, and provides an overview of research methods used in the investigation. The chapter concludes with a statement on delimitations, definitions of key terms, a brief summary, and an overview of remaining chapters in the dissertation.

\section{Background}

The relative academic underachievement of Black elementary and secondary school students in the United States has been given a great deal of attention by scholars, teachers, educational decision-makers, and others (McWhorter, 2000; Ogbu, 1990, 1991, 1978; Ogbu \& Simons, 1994, 1998; Soloranzo \& Yosso, 2001). Recent research addressing this concern has focused on the need for Black students to embrace positive attitudes toward educational attainment. Ogbu and Simons's (1998) cultural-ecological theory of school performance, which has received wide-spread attention, has emphasized the need for more attention to be placed on Black students' rejection of existing norms and values related to education as a key factor in improving the outlook for their success. 
The cultural-ecological theory of school performance, often referred to as the Ogbu thesis, examines the broad societal and school factors as well as dynamics within minority communities to explain academic performance of Black students. The theory argues that while discrimination and structural barriers in schools are important determinants of low school achievement among minorities, they are not the sole cause of low performance because not all minority students perform poorly in schools. Ogbu (1990) and others (Gibson \& Ogbu, 1991; Henke, 2001; Massey, Mooney, Torres, \& Charles, 2007; Ogbu \& Simons, 1994, 1998; Waters, 1994, 1999) point to evidence of the academic success of Black immigrant students. The Ogbu thesis identifies two forms of historical forces that shape different cultural models of minority groups that are relatively successful or unsuccessful in school. First, are the initial terms of incorporation of minorities, either voluntarily or involuntarily, into U.S. society. Second, are the patterns of adaptive responses that minorities have made to subsequent discriminatory treatment by members of the dominant group (Ogbu, 1990, 1991). For instance, voluntary minorities, as defined by Ogbu (1991) and Ogbu and Simons (1994, 1998), are those immigrant groups, such as Blacks from Africa and the Caribbean, who voluntarily move from their native lands into a new society in search of improved economic conditions, greater political freedom and better opportunities, overall. By contrast, involuntary minorities are defined as groups, such as U.S. non-immigrant Blacks, who have been forced into their present societies through slavery, conquest, or colonization (Ogbu, 1990, 1991; Ogbu \& Simons, 1994, 1998). Due to these differing cultural models, voluntary and involuntary minorities respond differently to the dominant group and its institutions, including schools. More specifically, Ogbu (1991) and Ogbu and Simons (1994, 1998) 
argue that voluntary minorities tend to develop positive attitudes toward school success, while involuntary minorities have ambivalent and contradictory attitudes toward schools. Despite its popular appeal, however, many tests of Ogbu and Simons's (1998) culturalecological thesis have been limited to a focus on qualitative and anecdotal data.

\section{Purpose of the Study}

One of the primary tenets of the Ogbu thesis is that Black immigrant students (mostly of African and West Indian heritage) outperform their non-immigrant (AfricanAmerican) counterparts and that these differences in academic success can be accounted for by cultural factors that shape differences in commitment to education in immigrant and non-immigrant Black families. Yet, evidence to support this major proposition of Ogbu's theory has been drawn primarily from qualitative rather than quantitative data and without directly comparing Black students from immigrant and non-immigrant families. The purpose of the present study is to address these shortcomings of previous research by testing Ogbu's theory through secondary analysis of quantitative data from a large international comparative study of reading literacy among young students, which permits direct comparisons between Black immigrant students in the U.S. (both first and second generation) and their non-immigrant counterparts. Data are drawn from the Progress in International Reading Literacy Study of 2001 (PIRLS).

Reports from PIRLS indicate that Black students score significantly lower than White students on reading literacy assessment. Black students are also the only ethnic group in the United States that does not score higher than the international average on three components of the reading literacy assessment (Ogle et al., 2003). This poor performance has been blamed on a host of factors: poor preparation, lack of motivation, 
and negative orientation of Black students toward schooling (McWhorter, 2000; Ogbu, 1990, 1991; Ogbu \& Simons, 1994, 1998; Soloranzo \& Yosso, 2001). Ogbu (1991) and Ogbu and Simons $(1994,1998)$, however, suggest that there are differences in minority student performance that are determined by differences in their community forces and their initial incorporation into society. This implies that changes are needed in cultural aspects of African American families and communities to produce success for African American children similar to that of Black immigrant students (Henke, 2001; Ogbu, 1990; Ogbu \& Simons, 1994, 1998; Waters, 1994). Although the Ogbu thesis has enjoyed popular support, criticism of the Ogbu arguments has pointed to the lack empirical evidence to support many of the tenets on which the thesis is based. For example, Ogbu's $(1978,1990,1991,1998)$ major studies were limited to specific communities in California and Ohio and consisted primarily of ethnographic and other qualitative data. Other empirical studies (Ainsworth-Darnell \& Downey, 1998, 2002; Farkas, Lleras, \& Maczuga, 2002; Fisher, 2005; Ford \& Harris, 1996; Harris, 2006; Hocschild, 1995; Rong \& Brown, 2001, 2002) have tested some tenets of Ogbu and Simons's (1998) theory, but those were limited to making comparisons of Black students overall to White students. Furthermore, many of these studies found that when controlling for sex and socioeconomic status, Black students are more likely to choose an academic curriculum and choose to attend a four-year college than their White counterparts (Ainsworth-Darnell \& Downey, 1998, 2002; Harris, 2006; Hocschild, 1995). These contradictions elicit the need for alternative perspectives when considering the educational experiences of immigrant and non-immigrant Black students in the United States. Direct comparisons of non-immigrant and Black immigrant children using 
empirical data are needed to confirm or refute Ogbu's theory. Therefore, the present study not only employs quantitative data to test the adequacy of the Ogbu theory, but also provides an alternative explanation by examining the issue from the perspective of segmented assimilation theory. This perspective argues that most post-1965 immigrants come to the U.S. lacking the political and economic resources necessary for easy transition into mainstream society. As a result, these immigrants tend to settle in the poor areas of their racial counterparts here in the U.S. Thus, over time, immigrants of color assimilate to the segmented culture of their immediate surroundings, not that of middle class, mainstream America (Portes \& Rumbaut, 2001; Portes \& Zhou, 1993). Therefore, the present study's purpose is also to extend explanations beyond factors other than terms of incorporation to account for the academic success of immigrant students.

General Statement of the Problem

Understanding the academic aspirations of minority students is of great interest in the U.S. This is particularly true for immigrant minority students, as the numbers of immigrant students entering U.S. schools are expected to steadily increase over the next 20 years. There have been numerous studies on the schooling of immigrant students from Mexico, Latin America, and the Spanish-speaking Caribbean; however, relatively little research has investigated the schooling of Black immigrant students.

According to the latest census estimates in 2005, the demographic composition of the United States is comprised of approximately $67 \%$ Whites, $14 \%$ Hispanics, and $12 \%$ Blacks (U.S. Department of Commerce, 2004). These figures, however, may not be reflective of the ethnic composition in some large, urban U.S. cities, especially in regions where large numbers of recent immigrants settle. For example, Miami, Florida's 
population consists of more than $50 \%$ Hispanics and $20 \%$ Blacks, with Whites being the ever-increasing minority (Fernandez, 2003). Furthermore, Miami-Dade County Public Schools (MDCPS), the fourth largest school district in the U.S., estimates that $25 \%$ of its students are foreign-born, and over $34 \%$ are identified as Black (Stepick, 1995). In many school districts, as in Miami, all students of African descent, except those from Spanishspeaking countries, are classified as Black without regard to country of origin or ethnic background.

A particular focus of the current study is the growth of Black immigrant groups in the U.S. While the proportion of Black immigrants to non-immigrant Blacks in the U.S. population is relatively small $(7.4 \%)$ as compared to other immigrant groups, their representation in the total population has been steadily increasing since 1990. Although these increases are small as compared to increases in Asian and Hispanic populations, they should, nonetheless, be of particular concern to education policy-makers, especially since some current research points to the higher educational achievement of foreign-born Blacks relative to non-immigrant Blacks (Gibson \& Ogbu, 1991; Henke, 2001; Massey, Mooney, Torres, \& Charles, 2007; Ogbu, 1990; Ogbu \& Simons, 1994, 1998; Waters, 1994, 1999).

This study compares the commitment to education among non-immigrant and immigrant Black students by examining their perceptions of education and reading literacy. Also, for the purposes of this study, reading performance is used as a measure of academic achievement because it is one of the most important abilities students acquire as they progress through the early school years. More importantly, reading, the foundation for learning across all subjects, can be used for recreation and personal 
growth, while equipping young children with the ability to participate fully in their communities and the larger society (Ogle et al., 2003). The Progress in International Reading Literacy Study of 2001 (PIRLS) (Ogle et al., 2003), is a large, international comparative study of the reading literacy of young students that focuses on the achievement and reading experiences of children in 35 countries in grades equivalent to fourth grade in the United States. Despite being conducted by the International Association for the Evaluation of Educational Achievement (IEA), very few studies have examined reading literacy using PIRLS and none have specifically examined the reading performance of non-immigrant and immigrant Black students in the United States.

Reports from the Progress in International Reading Literacy Study of 2001 (PIRLS) indicate that Black students score significantly lower than White students on reading literacy assessment. Furthermore, Black students are also the only ethnic group in the United States that does not score higher than the international average on three components of the reading literacy assessment (Ogle et al., 2003). These reports, however, have only looked at the performance of Black students overall and have not compared the performance of non-immigrant Black students to immigrant Blacks. Therefore, guided by these inconsistencies, the present study attempts to extend previous research by addressing two major research questions.

\section{Research Questions}

1. Do Black immigrant students differ from non-immigrant Black students in the United States in terms of attitudes toward reading, perceptions of reading selfconcept, and reading literacy based on the PIRLS 2001 assessment? 
2. Does Ogbu's theoretical distinction between voluntary and involuntary minority status or an alternative perspective (segmented assimilation) provide a more accurate explanation of non-immigrant and immigrant Black students' attitudes toward reading and reading literacy achievement?

Overview of the Research Method

This study used archived survey data from the Progress in International Reading Literacy Study of 2001 (PIRLS) (Ogle et al., 2003), a large international comparative study of the reading literacy of young students that focuses on the achievement and reading experiences of children in 35 countries in grades equivalent to fourth grade in the United States. Data were secured on a number of variables that tapped into the psychosocial development of participants, including attitudes toward reading, reading selfconcept, and demographic variables, such as ethnicity, gender, and immigrant status. Reading achievement was measured based on a written test of reading comprehension.

For the present study, a sub-sample of U.S. students who identify themselves as Black $(\mathrm{N}=525)$ was taken from the larger study. Within this category, students identified whether they were born in the U.S. $(\mathrm{N}=364)$ or born in a country other than the U.S. $(\mathrm{N}=161)$. Students were then recoded into the following categories: non-immigrant $(\mathrm{N}=439)$, foreign-born immigrant $(\mathrm{N}=39)$, and second-generation immigrant $(\mathrm{N}=47)$.

Data analysis consisted of descriptive statistics for an overall picture of the sample. Analysis of variance (ANOVA) was used to compare mean reading literacy assessment scores by immigrant status and sex. Additionally, multiple regression analyses were performed to determine which socio-cultural aspects of voluntary and 
involuntary minority life were related to reading literacy. A more detailed description of the research design and data analysis is presented in chapter 4 of the dissertation.

\section{Social Significance of the Study}

This study is a direct test of Ogbu's theoretical arguments related to differences between African American and Black immigrant children's academic orientations and performance in the context of voluntary and involuntary minority status and, thus, provides empirical evidence to inform policy-makers, school personnel and others in the larger community in planning effectively to meet academic needs of all children. The results of the present study offer empirical evidence related to theoretical notions offered by Ogbu and alternative explanations regarding the factors involved in understanding academic achievement of Black children in the U.S. related to literacy. The findings also form the basis for further investigation of academic performance of Black students in other areas as well as reveal insights into the ways that Black students perceive literacy and schooling in the U.S.

\section{Delimitations}

This dissertation examines the impact of immigrant status and socio-cultural factors, including measures of socioeconomic status (SES), on the reading performance of Black fourth-grade students in the United States. For the purposes of the current study, the measure for immigrant status was constructed from students' self-reported responses to questions regarding whether they and their parents were born in the United States. Additionally, parents' educational attainment and number of books in the home are the basis of the SES measure. Therefore, reliance on the accuracy of self-reported 
responses and a narrow measure of socioeconomic status must be taken into account in assessing the validity of findings from this study.

\section{Definition of Key Terms}

The following are definitions of key terms used throughout the present study:

\section{Black Immigrant}

Person of African-origin who has immigrated, or whose parents immigrated to the United States.

Dual Frame of Reference

Outlook adopted by immigrant groups that allows them to maintain an optimistic view of opportunities in their host societies as compared to opportunities that would be available in their homeland.

Foreign-born Immigrant

A citizen or resident of a particular country who emigrated from another country of origin.

Immigrant Status

The condition of a person's place of origin (i.e,, non-immigrant or immigrant).

Involuntary Minorities

Minority groups who have been forced into their present societies through slavery, conquest, or colonization.

Non-immigrant

A citizen of a particular country who was also born in that country. 


\section{Oppositional Identity}

Viewpoint adopted by involuntary minorities in which they reject education as they view it as an imposition of White culture on them.

\section{Plausible Values}

Imputed scores that represent estimates of achievement to ensure the accuracy of the estimates and for comparisons between subpopulations, as measured by responses to reading passages on the Progress in Reading Literacy Study of 2001.

\section{Reading Literacy}

The ability of an individual to understand and use the written language forms required by society and valued by the individual, as measured by responses to reading passages on the Progress in Reading Literacy Study of 2001 (Ogle et al., 2003).

\section{Second-generation Immigrant}

A citizen of a particular country who was born in that country, but whose parents emigrated from another country of origin.

\section{Segmented Assimilation}

The process by which immigrants of color with few economic resources tend to settle in the poor areas of their racial counterparts, and, thus, over time, assimilate to the culture of their immediate surroundings, and not necessarily that of the mainstream middle class.

\section{Voluntary Minorities}

Minority groups who voluntarily move from their native lands into a new society in search of improved economic conditions, greater political freedom and better opportunities overall. 
This chapter has introduced the present study and provided the background, general statement of the problem, social significance of the study and an overview of the research methods. The remaining chapters of this dissertation are organized into the various phases of the study. Chapter 2 presents a review of the relevant literature and discusses the theoretical underpinning and introduces the study's conceptual framework. Chapter 3 describes the methodology, focusing on the original (PIRLS) study from which data for the present study were derived and techniques employed in data preparation and analysis. Chapter 4 presents the results of the data analysis and reports the findings. Lastly, chapter 5 provides a discussion of the results and their implications for advancing theoretical understanding and educational policy. This chapter also offers overall conclusions and suggestions for future research. 


\section{CHAPTER II}

\section{REVIEW OF THE LITERATURE}

This chapter, through a review of the current literature, examines factors that contribute to the academic success or failure of Black students in the U.S., especially in terms of reading achievement. Two theoretical perspectives related to distinctions between non-immigrant and immigrant Blacks' attitudes toward education set the stage for the current study by providing a conceptual framework for the educational expectations and outcomes of minority students: (a) Ogbu and Simons's culturalecological theory of school performance (1998), and (b) segmented assimilation theory (1993). First, the chapter provides an overview of the state of education for Black students, with particular emphasis on Black immigrant students. Second, a discussion of Ogbu's classification schema used to distinguish between voluntary and involuntary minorities and the orientation toward the education of each group is presented. More specifically, the chapter discusses Ogbu's theoretical framework in relation to minority students' success in reading. Third, the chapter provides a synthesis of recent studies that have examined the academic performance of Black students in the United States, with particular attention to those that have focused on ethnic differences among Black students. Finally, the chapter ends with the presentation of segmented assimilation theory as an alternative explanation for the academic success or failure of minority students, particularly as it relates to educational opportunities of immigrants of color.

Overview of the State of Education for Black Students

Since 1980, the U.S. population has become more diverse in terms of minority population growth, and by 2005 minorities made up $33 \%$ of the total U.S. population. 
However, not all groups have grown at the same rate. For example, the population of Asians/Pacific Islanders has grown 260\% and the Hispanic population has grown 192\% to surpass Blacks as the largest minority group in the U.S. (U.S. Department of Commerce, 2001). The Black population had the slowest population growth of all minority groups in the U.S. at $39 \%$ since 1980 . For the next 15 years, the minority population is expected to steadily increase and by 2020 , minorities are predicted to make up $39 \%$ of the total U.S. population (KewalRamani, Gilbertson, Fox, \& Provasnik, 2007; U.S. Department of Commerce, 2004).

This growth in minority group populations can be partially explained by recent increases in immigration. Since 1990, the size of the immigrant (foreign-born) population in the U.S. has grown from $8 \%$ to $12 \%$ in 2005 . More specifically, in 2005 $4 \%$ of all U.S. children under the age of 18 were born outside of the U.S. (KewalRamani et al., 2007). This growth in immigrant populations, and particularly that of children under the age of 18 , has important implications for education policy in the U.S. (Glick, 2004; KewalRamani et al., 2007).

There is a popular perception that immigrant groups who come to the U.S. are largely undereducated (Portes \& Rumbaut, 1990) and have become more so over the past 30 years. Research shows, however, that although immigrants from Mexico and other Central American countries tend to have low levels of education as they enter the U.S., overall, immigrants are entering the U.S. with higher levels of education than they did prior to 1970 (Portes \& Rumbaut, 1990). As in the non-immigrant population, however, there is a great deal of diversity in the educational attainment of immigrant groups. Immigrants from Africa, for example, tend to be among the most highly educated of all 
immigrant groups. This is due largely to the fact that post-1965 immigration laws imposed two requirements on African (as well as Asian) immigrants: family reunification and occupational qualifications (Portes \& Rumbaut, 1990). Although now changing, few African immigrants historically have had family members already residing in the U.S., therefore, they had to rely on their higher education levels, and, thus, occupational credentials for entry into the country (Portes \& Rumbaut, 1990). For these African (and Asian) immigrants, the U.S. presents a chance for upward mobility that may have been limited in their home countries. This is due to the reality that many were from undeveloped nations in which there were few opportunities for the highly educated (Portes \& Rumbaut, 1990).

A particular interest of the current study is the growth of Black immigrant groups in the U.S. While the proportion of Black immigrants to non-immigrant Blacks in the U.S. population is relatively small $(7.4 \%)$ as compared to other immigrant groups, their representation in the total population has been steadily increasing since 1990 . For example, in 1990, immigrant Blacks made up $4.2 \%$ of the total Black population in the U.S. By 2000 , that number had grown to $6.3 \%$, and children under the age of 18 represented $1.9 \%$ of the total Black population of children under 18. Still, by 2005 the percentage of immigrant Blacks had increased to $7.4 \%$ and the number of under-18-yearolds had risen to 2.3\% (KewalRamani et al., 2007; U.S. Department of Commerce, 2005). Although these increases are small as compared to increases in Asian and Hispanic populations, they should, nonetheless, be of particular concern to education policymakers, especially since some current research points to the higher educational achievement of foreign-born Blacks relative to non-immigrant Blacks (Gibson \& Ogbu, 
1991; Henke, 2001; Massey et al., 2007; Ogbu, 1990, 1991; Ogbu \& Simons, 1994, 1998;

Waters, 1994, 1999).

In contrast to the educational attainment of African immigrants entering the U.S., research on the academic achievement of Black students often depicts poor academic performance. An area of particular concern is reading literacy. For example, findings from the Progress in International Reading Literacy Study of 2001 (PIRLS) indicate that Black students score significantly lower than White students on reading literacy assessment. Black students are also the only ethnic group in the United States that does not score higher than the international average on three components of the reading literacy assessment (Ogle et al., 2003). The relatively lower performance of Black students in the U.S. has been attributed to a host of factors ranging from poor preparation and lack of motivation to the negative orientation of Black Americans toward schooling (McWhorter, 2000; Ogbu, 1990, 1991; Ogbu \& Simons, 1994, 1998; Soloranzo \& Yosso, 2001). These issues, along with the rise in immigrant populations, are part of what led John Ogbu on a quest to explain the achievement deficiencies among minority students, particularly Black students and immigrant students.

John Ogbu and the Classification Schema of Minorities

The work of John Ogbu first gained national attention with the 1978 book, Minority Education and Caste: The American System in Cross-Cultural Perspective. The research which led to this book began in 1970 and was conducted while he was a staff member of the Carnegie Council on Children. While in this post, Ogbu became interested in the achievement gaps between dominant and minority groups, and particularly between Blacks and Whites in the United States. This work was in response 
to popular assumptions made by social scientists at the time that attempted to explain the differences. In this early work, Ogbu found that these early theories inadequately concluded that the three major factors that determined children's school performance were home environment, school environment, and heredity. The formal explanations of how these forces operated were contained in theories that were particularly popular in the early 1970s, including: cultural deprivation theory, cultural conflict theory, institutional deficiency theory, educational inequality theory, and Jensen's (1969) heredity theory (Ogbu, 1978).

Cultural deprivation theory suggested that Black students performed poorly in school because they had deficient cognitive and linguistic skills that would promote a White middle-class type of school success. Cultural conflict theory, on the other hand, assumed that Black students did possess their own cognitive and linguistic skills, but they were not recognized by schools for instructional purposes. Ogbu rejected social class as a factor in Black students' poor school performance, citing that middle class Black students still do not perform as well as their White counterparts, and that the achievement gap between lower class and middle class Blacks is not as great as the gap between lower class and middle class Whites (Ogbu, 1991; Van den Berghe, 1980; Wilson, 1980). Furthermore, Ogbu (1991) contended that Black students' academic achievement was not strongly correlated with parents' education, income or socioeconomic status (Haycock \& Navarro, 1988; Slade, 1982).

Institutional deficiency theory purported that schools were designed from the outset to promote failure among Black students, while educational inequality theory blamed Black students' poor school performance on the schools' inability to provide 
adequate remedial programs to counteract the negative educational influences of Black homes and communities. While these two theories did identify the responsibility of the schools in failing to provide equitable opportunities and resources to Black students, Ogbu believed that they failed to address the impact of social and racial stratification on school systems.

Perhaps, the most damaging, yet largely accepted, theory was Jensen's (1969) heredity theory. In 1969 Jensen wrote, "How Much Can We Boost IQ and Scholastic Achievement" for the Harvard Educational Review. In this article, Jensen (1969) surmised that Blacks performed poorly in school because they had "inferior genetic endowments for certain kinds of intellectual skills" (as cited in Ogbu, 1978, p. 55). Ogbu, again, rejected this explanation, citing that poor-performing, caste-like minorities in one society do, indeed, perform well, when in another society that does not ascribe them to caste-like status (Ogbu, 1991).

Convinced that these contemporary theories neglected to look at the impact of social stratification and ascribed status on educational opportunities, Ogbu embarked on a journey of research that would examine what he called America's caste-like system of racial stratification as the predominant cause of Black students' lower school performance (Ogbu, 1978). He believed that much of the research on the academic performance of minority students overlooked the existing forces within society that influence academic efforts, understanding of the educational system, and perceived benefits of academic success. Therefore, Ogbu's seminal work sought to explain how American society's refusal to provide Black Americans adequate opportunities for 
desirable occupations in adult life is directly related to lack of access to quality education, and, thus, lowers school performance of Black students (Ogbu, 1978).

Determined to examine the impact of access to desirable occupations on the school performance of Black students, Ogbu questioned whether American folk beliefs about education among both Black and White families reflected the true function of the formal education system. Popular folk beliefs about education, for example, were futureoriented in that parents believed that the function of education was to "prepare children to compete for and successfully perform the typical adult roles in their society by transmitting the necessary motivational, cognitive, and other skills required by such roles" (Ogbu, 1978, pp. 16-17). In fact, most American parents, Black and White, would instill in their children that more education would lead to higher social status, greater self-esteem, and better employment opportunities, jobs and salaries (Ogbu, 1978). Ogbu argued, however, that the education of Blacks (and other caste minorities) was not designed to prepare students for life in mainstream America, but to equip them with "suitable qualities for their lower positions in society" (Ogbu, 1978, p. 26). Therefore, according to Ogbu (1978), even though Black families may have shared the same folk beliefs about education as White middle-class families, children did not have regular interaction with people in the community who had achieved levels of academic and occupational success comparable to that of mainstream America. Consequently, according to Ogbu, Blacks' limited educational and occupational opportunities led them to be less motivated to perform well in school (Ogbu, 1978).

Ogbu did not limit his theories to only Black Americans, as he found similar patterns among other "caste-like" minorities in the United States, including Mexican- 
Americans, native Indian-Americans, and Puerto Ricans; nor did he claim that such phenomena were exclusive to the United States, but that other societies with caste-like stratification faced similar achievement gaps between dominant and minority groups. In fact, in these cases, the stratification was truly based on caste, as opposed to race in the U.S., as the Maoris in New Zealand, Burakumin in Japan, and Oriental Jews in Israel were of the same race as the dominant groups in their respective societies (Ogbu, 1978).

In this early work, however, Ogbu encountered the difficulty involved in trying to compare the educational experiences of students of the dominant groups to minority students, especially in the U.S., where most non-Whites were defined as minorities. He took exception to this dichotomous classification as there were, indeed, some minority groups who performed as well as Whites in school and the labor market. As a result, Ogbu (1978) found it necessary to further analyze minorities in terms of three different types: autonomous minorities, caste minorities, and immigrant minorities.

According to Ogbu (1978), autonomous minorities often possessed distinct cultural, ethnic, or religious identities from the dominant group, but these groups did not necessarily regard the dominant group as their reference group, nor did they necessarily desire to assimilate. Mormons and Jews in the U.S. would be categorized as autonomous minorities according to this definition. Caste minorities, such as Black Americans, on the other hand, are usually regarded as inferior by the dominant group, yet the dominant culture is the only successful frame of reference for these groups. Immigrant minorities, however, fell somewhere between autonomous and caste minorities according to Ogbu's classification. Immigrants, who move to a new host society more or less voluntarily, could compare their new situations to less desirable conditions back home (Ogbu, 1991). 
As a result, immigrants would express gratitude for whatever opportunities were extended to them in their new homes (Ogbu, 1978, 1991). This new perspective by Ogbu would be instrumental in the development of his Cultural-Ecological Theory of School Performance.

Ogbu and Simons's Cultural-Ecological Model of School Performance

Ogbu and Simons's (1998) Cultural-Ecological Theory of School Performance was developed to address the broad societal and school factors as well as dynamics within minority communities in terms of their impact on academic performance among minority students. The theory argues that, while discrimination and structural barriers in schools are important determinants of low school achievement among minorities, they are not the sole cause of low performance because not all minority students perform poorly in schools. Rather, Ogbu and Simons $(1994,1998)$ suggest that differences in minority student performance can be attributed to differences in community forces that are determined by differences in incorporation into society, either voluntarily or involuntarily. This theory, however, was an extension of Ogbu's earlier work as he searched for a more adequate explanation of the differences in minority students' school performance.

Ogbu (1991) and Ogbu and Simons (1998) suggested that differences in minority students' school performance be examined through the use of cultural models, because it was "necessary to incorporate the perceptions and understanding that minorities have of their social realities and of their schooling" (pp. 6-7). The type of cultural model adopted by a minority group depends on whether they were initially incorporated into their host society voluntarily or involuntarily (Ogbu, 1990, 1991; Ogbu \& Simons, 1994, 1998). 


\begin{tabular}{|c|c|}
\hline “THE SYSTEM" & "COMMUNITY FORCES" \\
\hline \multirow{2}{*}{$\begin{array}{l}\text { Societal Educational Policies } \\
\text { and Practices }\end{array}$} & Dual Status Frame of Reference \\
\hline & \multirow{2}{*}{$\begin{array}{l}\text { Instrumental Beliefs about } \\
\text { Interpretations of Schooling (e.g., } \\
\text { Role of Credentials in Getting Ahead) }\end{array}$} \\
\hline \multirow{2}{*}{$\begin{array}{l}\text { Societal Rewards for } \\
\text { Educational Accomplishments } \\
\text { or Credentials }\end{array}$} & \\
\hline & \multirow{2}{*}{$\begin{array}{l}\text { Relational Beliefs about or } \\
\text { Interpretations of Schooling (e.g., } \\
\text { Degree of Trusting Schools and Those } \\
\text { in Control; Schooling as a Process of } \\
\text { Subordination and Control) }\end{array}$} \\
\hline \multirow[b]{2}{*}{$\begin{array}{l}\text { Treatment of Minorities in } \\
\text { School }\end{array}$} & \\
\hline & $\begin{array}{l}\text { Symbolic Beliefs about Interpretations } \\
\text { of Schooling (e.g., Is learning } \\
\text { curriculum, school cultural practices } \\
\text { and language a threat to minority } \\
\text { cultural and language identity?) }\end{array}$ \\
\hline \multicolumn{2}{|c|}{ MINORITY EDUCATIONAL STRATEGIES } \\
\hline \multicolumn{2}{|c|}{ SOCIAL ADJUSTMENT \& ACADEMIC ACHIEVEMENT } \\
\hline
\end{tabular}

Figure 1. Cultural-Ecological Theory of School Performance Conceptual Framework Source: Ogbu, J., \& Simons, H. (1998). Voluntary and Involuntary Minorities: A Cultural-Ecological Theory of School Performance with some Implications for Education. Anthropology \& Education Quarterly, 29(2), $155-188$. 
Immigrant minorities, who Ogbu (1991) and Ogbu and Simons $(1994,1998)$ referred to as voluntary minorities, are those groups who moved to their present societies in search of economic and political freedom and better opportunities overall. Immigrants are characterized by primary cultural differences that exist within the group before they arrive in their adopted land and become minorities. From this perspective, Ogbu (1991, $2003)$ and Ogbu and Simons $(1994,1998)$ argue that successful minority groups possess a different understanding of the workings of the larger society and their place in that working order compared to the views of less successful minorities. For example, Ogbu (2003) explains that immigrants do not interpret their presence in the United States as having been forced on them by White Americans. Ogbu further asserts that voluntary minorities develop "pragmatic trust in societal institutions, such as the schools, for instrumental reasons" (Ogbu, 2003, p.50). Ogbu (2003) argues that descendants of voluntary minorities, regardless of generation, continue to be voluntary minorities, and thus, retain the educational ideas, attitudes and behaviors of their forebears.

In contrast, Ogbu and Simons $(1994,1998)$ define non-immigrant minorities as involuntary. Involuntary minorities, such as non-immigrant Blacks, have been forced into their present societies through slavery, conquest, or colonization (Ogbu, 1990; Ogbu \& Simons, 1994, 1998). Accordingly, involuntary minorities are characterized by secondary cultural differences that develop after they become minorities. Furthermore, Ogbu contends that involuntary minorities resemble individuals existing in a caste-like system where status and group membership are determined at birth (Ogbu, 1978).

Both voluntary and involuntary groups are subject to discriminatory treatment by the dominant group in the form of limited access to desirable jobs and quality education 
and social and political barriers. According to Ogbu (1991) and Ogbu and Simons (1994, 1998), however, voluntary and involuntary minority groups react to the same social situation differently. Specifically, voluntary and involuntary minorities differ in their cultural models in five ways: (a) a frame of reference for comparing present status and future possibilities; (b) a folk theory of getting ahead; (c) a sense of collective identity; (d) a cultural frame of reference for judging appropriate behavior and affirming group solidarity; and (e) an assessment of the extent to which one may trust members of the dominant group and the institutions they control (Ogbu, 1991; Ogbu \& Simons, 1994, 1998). The research by Ogbu $(1978,1990,1991)$ and Ogbu and Simons $(1994,1998)$ sparked widespread interest in the educational achievement of minority students, particularly Black and immigrant students. However, since much of the later criticism of these earlier formulations center around Ogbu's thesis that modes of immigrant incorporation into the host society (voluntary versus involuntary) determined achievement of minority students, this study shall turn to a closer examination of differences between voluntary and involuntary minorities.

\section{Voluntary Minorities}

Dual frame of reference. Ogbu (1991) and Ogbu and Simons $(1994,1998)$ argued that voluntary minorities interpret the economic, political and social barriers against them as temporary-problems they will overcome with time, hard work and more education. As a result, they develop a positive dual frame of reference which allows them to develop an optimistic view of their future opportunities as compared to their former situations "back home." For example, by developing a positive dual frame of reference, voluntary minorities are able to express gratitude for whatever opportunities they have in their host 
societies, no matter how menial, as compared to opportunities that would be available in their homeland, recognizing that if things do not work out in their host society, they can always go back (Gibson \& Ogbu, 1991; Ogbu, 1990, 1991; Ogbu \& Simons, 1994, 1998). Furthermore, Ogbu $(1990,1991)$ and Ogbu and Simons $(1994,1998)$ argue that voluntary minorities develop a folk theory of getting ahead, where they believe that education is key to status mobility (Ogbu, 1990, 1991; Ogbu \& Simons, 1994, 1998; Suarez-Orozco, 1991). As a result, parents of voluntary minority students have high academic expectations for their children to succeed and tend to hold them responsible for their own academic performance. Voluntary minorities also tend to accept the discrimination they may experience as a temporary consequence of their status as foreigners in a new land (Gibson, 1991; Ogbu, 1990, 1991; Ogbu \& Simons, 1994, 1998; Suarez-Orozco, 1991). Other researchers have also examined whether a positive dual frame of reference is a factor in the academic success of immigrant students. A Canadian study by Samuels, Krugly-Smolska, and Warren (2001), for example, found support for the dual frame of reference explanation. In that study of 1,954 urban high school students (in Vancouver and Toronto), findings revealed that, by making comparisons to earlier experiences in schools "back home," most voluntary immigrant students, appreciated the positive aspects of their new school. Although most students in the study expressed interest in pursuing post-secondary education, native Canadian males held the lowest aspirations for pursuing a university-level education. While these findings are relevant, they are not generalizable to the U.S. Furthermore, there was no involuntary comparison group.

In another study, Rong and Brown (2002) conducted a meta-analysis of research (20 years) on the life experiences of Caribbean and African Black immigrants and their 
children and the processes by which they were incorporated into American society and its educational system. That study found that empirical research suggested a "triple disadvantage" or "model Black" dichotomization of immigrant Blacks. For example, Dodoo (1997) described Caribbean Blacks as high achievers because they have a more favorable social climate in the Caribbean (racial majority and positive role models). Additionally, they bring a different cultural history and strong desire to overcome their immigration status and race (Omi \& Winant, 1986; Sewell, 1981). Findings from the meta-analysis also revealed that Black immigrant students who opt to maintain their immigrant identity expect mainstream America to respond positively to that choice, yet those who identified with non-immigrant Blacks anticipated less reward for their efforts, focused more on discrimination, and performed less well in school (Foner, 1987; Gibson, 1991; Kasinitz, 1992; Waters, 1991, 1994, 1999; Woldemikael, 1989). Bashi and McDaniel (1997), however, concluded that although Caribbean Blacks may initially distinguish themselves from the general American/non-immigrant Black population, over time the differences will become less apparent and their descendents will become American/non-immigrant Blacks.

Folk theories of success. Another factor that Ogbu and Simons $(1994,1998)$ contribute to the nature of immigrant adaptation is the fact that they already have, and try to retain, a sense of identity that they bring to their new host society. In an effort to retain and distinguish their separate identity from non-immigrant Blacks in the U.S., Black immigrants often dissociate themselves from non-immigrant Black Americans because, in their view, it improves their economic status (Bryce-Laporte, 1972; Ogbu, 1991; Ogbu \& Simons, 1994, 1998; Waters, 1991, 1994, 1999). For example, some anthropological 
research (Gibson \& Ogbu, 1991; Henke, 2001; Waters, 1994, 1999) has shown that Black immigrants, particularly those from the Caribbean, clearly recognize and try to retain a separate identity from non-immigrant Black Americans, because "assimilation to Black America is downward mobility" (Waters, 1999, p. 65).

Furthermore, ethnographic studies by Waters $(1994,1999)$ reveal that for many Caribbean Blacks, West Indian identity is retained by designating themselves as "other" rather than choosing to identify as "Black," which is the designation chosen by nonimmigrant Blacks. Many Caribbean respondents in her 1991 New York study revealed that they viewed themselves as superior to non-immigrant Blacks and that the two groups were "looking in different directions, having different motivations" (Waters, 1999, p.65). Many held stereotypical images of non-immigrant Blacks as lazy, welfare-dependent and prone to deviant behavior. In another study by Henke (2001), Caribbean immigrants expressed the view of education as the most promising way to a better life-a "privilege rather than a basic right" (p. 133). Yet many black immigrants hold the perception that non-immigrant Blacks do not value education and do not take advantage of the opportunities available in the U.S. (Henke, 2001; Waters, 1994, 1999).

A study by Kao and Tienda (1995) found that the relationship of generational status to indicators of educational achievement differ by race and ethnicity. Using data from the 1988 National Education Longitudinal Survey (NELS:88), the researchers examined the educational attainment of over 24,000 first, second and third generation immigrant eighth-grade students. Among Black students, the study found that birthplace was a predictive factor in educational achievement. Furthermore, first generation students outperformed second-generation and non-immigrant Blacks in terms of grades 
and math scores, while second-generation students had the highest achievement in reading. This higher achievement of first and second generation Blacks suggests that immigrant youth may be more highly motivated to achieve academically. Interestingly, however, all Black students demonstrated educational aspirations equivalent or higher to those of Whites from comparable backgrounds, despite lower academic performance. This finding contradicted Ogbu's assertion that non-immigrant Black students develop ambivalent and contradictory attitudes toward schooling.

A related study by Butcher (1994) examined wages of Black and White immigrant and U.S. natives using 1980 Census data from the Public Use Sample. In that study, Black immigrant males were compared to movers-native born males who, as of 1979 , resided in a state other than their birth state, and non-movers-native born males who resided in their birth state. Butcher (1994) observed that the success of Black immigrants may have been more associated with intrinsic differences between those who migrated and those who didn't than with the "cultural traditions" of native born Blacks.

Interestingly, however, the study also found that returns to education were significantly lower for immigrant Black men than they were for non-immigrant Blacks. Furthermore, at low levels of education, immigrant Blacks were more successful than native Blacks, but at higher levels of education, non-immigrant Blacks surpassed Black immigrants in terms of labor market success. The study also found that Jamaican immigrants and native Black movers showed similar patterns with respect to returns to education. This indicated that of moving from one's birth place, whether it be a different state or a different country, was a positive factor in determining labor market success. The study by Butcher (1994) was limited in that it did not measure academic achievement 
and included only a limited number of other educational attainment measures. There were also no females included in the study, which prevented gender comparisons.

Yet another related study, (Massey et al., 2007), analyzing data from the National Longitudinal Survey of Freshman to examine characteristics of non-immigrant and immigrant Black college students, concluded that there were positive and non-significant differences among these groups in college academic achievement. There were differences between non-immigrant and immigrant students in college enrollment, but significant differences were found only in the most prestigious universities. In terms of the college admissions process, immigrant students were not more favored per se, but said to exhibit traits and characteristics valued by admissions committees (i.e., high school GPA, quality of high school, participation in Advanced Placement courses, etc.). Still, there were no significant differences in academic achievement at the college level, as measured by college GPA.

Involuntary Minorities

Collective identity. In comparison to voluntary minorities, involuntary minorities in Ogbu's view, perceive economic, political and social barriers against them as permanent problems and have no "back home" to compare (Ogbu, 1991; Ogbu \& Simons, 1994, 1998). Furthermore, Ogbu (1991) and Ogbu and Simons $(1994,1998)$ argue that involuntary minorities do not view their cultural differences from the dominant group as obstacles to be overcome, but rather as institutionalized markers of group identity to be maintained (Gibson \& Ogbu, 1991; Ogbu, 1990, 1991; Ogbu \& Simons, 1994, 1998). According to Ogbu and Simons $(1994,1998)$, involuntary minorities develop their sense of identity after being incorporated into the present host society. As a 
result, involuntary minorities develop a negative dual frame of reference with respect to status mobility. Furthermore, this process is assumed to emerge as a secondary cultural system in which involuntary minorities develop, and try to maintain, language, cultural, and belief systems that are different from, and in opposition to, the dominant group (Ogbu, 1990, 1991; Ogbu \& Simons, 1994, 1998).

A survey of high school seniors in eight public high schools in Los Angeles by Michelson (1990) revealed that Black students have dual attitudes toward education. These students held abstract attitudes that reflect the dominant ideology and weak concrete attitudes. Michelson attributed the low academic performance among Black students to poor quality of schools. Still, Black students were significantly more likely to embrace the dominant ideology toward education than their White counterparts, although their concrete attitudes were significantly more pessimistic than those of similar Whites. Furthermore, abstract attitudes had no relationship to grades, while concrete attitudes had a significant positive relationship to high school grades. Race, however, was the single most powerful predictor of GPA. The shortcomings of that study in terms of its relevance for the present study is that the findings are not generalizable, because the sample was not random, consisting of students selected from eight Los Angeles high schools. Also, no distinctions between non-immigrant and immigrant Blacks were made.

Oppositional identity. Involuntary minorities, according to Ogbu (1991) and Ogbu and Simons $(1994,1998)$, often express the wish of succeeding through hard work and education, but they do not believe that this strategy works for them. As a result, they believe that getting ahead requires not only education, but a collective struggle against the barriers placed before them. Therefore, Ogbu (1991) and Ogbu and Simons (1994, 
1998) suggest that involuntary minorities develop ambivalent and contradictory attitudes toward schooling. They continue to state that, on one hand, involuntary minorities endorse the importance of education for academic and future job success. On the other hand, many hold a general mistrust of the dominant group, its institutions, and schools in terms of equality of opportunity and future economic rewards (Ogbu \& Simons, 1994, 1998). Consequently, Ogbu and Simons $(1994,1998)$ assert that involuntary minorities develop an oppositional identity to the dominant society and view the schools and their curricula as an imposition of the dominant culture on them, standing at the root of their academic failure, and thus, an institution that cannot be trusted (Ogbu, 1990, 1991).

Ogbu and Simon's 1994 study, using data from the Minority Education Project, a survey of 5th through 12 th grade minority students in Oakland, California, found that involuntary minorities are ambivalent toward education. For example, they were less likely to have heard their parents say "America is the land of opportunity." Involuntary minorities were also more likely to cite unfair treatment, and racial prejudice. They reported that Whites do not see them as smart, and they did not foresee any improvements in opportunities for the future. Still, Ogbu and Simons found that AfricanAmericans and Chinese-Americans report equally high percentages of wanting to go to a 4-year college or beyond. This contradicts Ogbu and Simons' (1998) own assertion that non-immigrant Black students are "skeptical and ambivalent about the role of education" (p. 173). That study was limited by a survey instrument which contained mostly attitudinal items with no measure of actual achievement. Additionally, the results were presented as group comparisons only (using percentages), and no significance tests were 
reported, even though the methodology section indicates that the chi-square statistic was used. Finally, many of the questions in the survey were culturally biased or leading.

There have been many other studies that question the existence of oppositional identity among Black students and its potential impact on their academic performance. For instance, Ford and Harris (1996) investigated the perceptions and attitudes of Black students toward school, achievement, and other educational variables using data from a study of 148 Black elementary students in an urban Ohio city and found that most of the students held high regard for achievement and working hard in school. However, there was a reported discrepancy between students' tenets of achievement ideology and achievement behaviors. These findings were limited by the study's lack of generalizability due to the small sample size. Furthermore, no measure of academic achievement was included and the study did not distinguish between non-immigrant born and immigrant Blacks.

The "burden of acting White." As an extension of the notion of oppositional identity, Ogbu's, research with Signithia Fordham attempted to find explanations for nonimmigrant Black students' ambivalent and contradictory attitudes toward schooling. Based on this work, they concluded that some non-immigrant Black students did, indeed, perform well in school, but in doing so had to employ the particular strategy of developing a "raceless" persona (Fordham, 1988; Fordham \& Ogbu, 1986; Ogbu, 2004). Fordham and Ogbu (1986) reported that these students experienced ridicule from their peers due to their perception that performing well in school is perceived by their peers as "acting White," thus, to desire success in school performance also carries the burden of being perceived by valued peers as "acting White." 
Fordham (1988) and Fordham and Ogbu (1986) posit that the heart of the struggle for Black students is having to "choose between the individualistic ethos of the school and the collective ethos of their community" (Fordham, 1988, p.55). According to Fordham, high achieving students reconcile this dilemma by either socially distancing themselves from their peers or undermining the idea of group solidarity (Fordham, 1988). Furthermore, Fordham asserts that the schools, themselves, value the raceless persona adopted by high achieving Black students (Fordham, 1988).

Farkas, Lleras, and Maczuga (2002) used data from the National Education Longitudinal Study (NELS) and one item from the National Assessment of Educational Progress (NAEP) to determine whether oppositional culture exists in minority and peer groups. The findings revealed a significant positive interaction between race and being a very good student only among students attending schools that are less than $25 \%$ White. More specifically, being a very good student for Black males and females significantly increases their chances of being put down by their peers. In a more recent study by Fisher (2005), partial support for oppositional identity was found. However, Fisher's contention that some students faced rejection from teachers rather than developed an oppositional culture was limited by evidence based on qualitative data from an exploratory study of only 14 students at an urban Massachusetts high school. Furthermore, while that study asked teachers to identify students as high-achieving or low-achieving, no objective measure of academic achievement was used. Therefore, a risk of teacher subjectivity or bias existed. Contradictory to Fordham (1988) and Fordham and Ogbu's (1986) "acting White dilemma," the study revealed that some of the students identified as low-achievers reported that being smart and Black is "cool." 
Most studies that have examined the existence of oppositional identity and the "burden of acting White" among Black students have failed to find support for Ogbu and Simons's claim. Using data from the first follow-up of the 1990 National Education Longitudinal Study (NELS), Ainsworth-Darnell and Downey $(1998,2002)$ conducted two studies in which they found that, overall, African-American students report more positive attitudes toward school than do Whites. African-American students were also significantly more likely than White students to report that they believe education is important to getting a job later on. Furthermore, Ainsworth-Darnell and Downey found no significant difference between Black students and White students in response to support for the survey items "my friends make fun of people who try to do well in school," and "relative to White students, African-American students are especially popular when they are seen as very good students" (Ainsworth-Darnell \& Downey, 2002). While these studies used very large random samples, they did not distinguish between non-immigrant and immigrant Black students.

Using 1990 NELS data, Roscigno and Ainsworth-Darnell (1999), found that family background is important for educational success. Inequalities in family background help to explain racial gaps in achievement, and race-based micropolitical processes in schools may be important in the evaluation and rewarding of background attributes. Even though that study found significant racial gaps in students' GPAs and mathematics-reading achievement, those gaps are explained by SES and family structure differences across racial groups. While the studies by Roscigno and Ainsworth-Darnell (1999) Ainsworth-Darnell and Downey (2002), and Farkas, Lleras, and Maczuga (2002) 
produced evidence based on quantitative data from large, national random samples, none of these studies distinguished between non-immigrant and immigrant Black students.

In a qualitative study of 56 elementary students in a large southeastern U.S. city, Tyson (2002) found no support for the oppositional culture thesis. Tyson reported that Black students enter school oriented with pro-school attitudes, including positive attitudes toward academic achievement. School experience plays a significant role in the development of attitudes toward school. Tyson found that students reported that highachieving students were ostracized by their peers only in cases where these students were boastful. All of the students openly expressed enthusiasm for learning and academic achievement. However, all of the students in that study were from middle-class backgrounds, which probably influenced pro-school and pro-achievement attitudes as well as teachers' perceptions and treatment of the students.

More recently, in a study of 3,665 Maryland middle school and high school students, Harris (2006) found that Black students have greater affect toward school and rate enjoyment of classes as more important for their school attendance than Whites, although the difference narrows by $11^{\text {th }}$ grade. Harris also found no significant difference between high-performing Blacks and Whites in terms of getting along with peers. Most importantly, the study found that an equal proportion of poor-performing Blacks and high-performing Blacks equated good school performance to "acting White," indicating inconsistency with the "burden of acting White" thesis.

As evident from this review of research found in the literature, there are inconsistencies in the findings related to Black student academic achievement and oppositional identity. This suggests that there may be other factors that account for the 
academic success or failure of Black students. Furthermore, the contradictory findings in the literature elicit the need to search for other theoretical explanations that may provide alternative perspectives in attempts to better understand the academic performance of minority and immigrant students.

Also evident from the review of the relevant literature, many studies have failed to make direct comparisons between non-immigrant and immigrant Black students. In those that did make such comparisons, some pointed out that even though in some cases the immigrant students tried to maintain a separate identity from the non-immigrant Blacks, the dominant group often did not see such differences and over time the differences became less evident. Therefore, a need for an alternative explanation of the differential academic performance of immigrant and non-immigrant Black students is clearly evident.

\section{Segmented Assimilation Theory}

The present study draws upon the perspective of segmented assimilation theory as an alternative explanation of the academic experiences of immigrant students as a part of a larger assimilation process. Segmented assimilation theory argues that most post-1965 immigrants have come to the U.S. lacking the political and economic resources necessary for easy transition into mainstream society. As a result, these immigrants tend to settle in the poor areas of their racial counterparts here in the U.S. Thus over time, immigrants of color assimilate to the segmented culture of their immediate surroundings, not that of middle class, mainstream America (Portes \& Rumbaut, 2001; Portes \& Zhou, 1993).

Much attention has been given to the education of minority students, especially ethnic minorities. As a nation built on the foundations of immigrants, the U.S. has 
always had to contend with the impact that schooling has on these groups. The U.S. has always prided itself in being a great "melting pot" (Gordon, 1964) in which different groups come together and blend into one American society. Traditional assimilation theories have supported this concept by promoting the idea that groups will, over time, acquire the customs and values of their host nation that will replace their existing customs.

Early assimilation theories were based on the ideology of Anglo-Conformity, suggesting that minority immigrant groups would inevitably be socialized into the mainstream middle-class, Anglo-Saxon Protestant cultural patterns of American life (Alba \& Nee, 1997; Gordon, 1964; Park \& Burgess, 1969). The cultural standard to which all groups were to aspire was the core cultural patterns of middle class, White, Anglo-Saxon Protestant origins (Gordon, 1964). Thus, according to this view immigrant groups will completely assimilate into the U.S. population within a few generations. For early immigrant groups this may have been largely true. Until the 1960s, most people emigrating to the U.S. were of European descent. While there were ethnic and religious clashes between immigrant and the non-immigrant population and among ethnic groups, there was still one unifying element-their European heritage and White skin color. Therefore, within a few generations, groups such as Irish Americans, Italian Americans, and Polish Americans would simply become Americans, even though they were not primarily Protestants. This notion of the American "Melting Pot" was popular through much of U.S. history, and particularly in the years immediately following World War II (Alba \& Nee, 1997). What the traditional assimilation theories failed to address, however, is the incorporation of non-European immigrants into the U.S. society. 
Despite best efforts to claim that all peoples within the U.S. eventually assimilate into the mainstream, history proves that assimilation for some groups has been difficult at best. For example, Chinese immigrants who were recruited to help build the nation's railroad system were constantly denied access to many of the privileges of American society. Japanese Americans, during World War II, were held in detention camps to curb fears of Japanese hostility. Over time, these overt discriminatory practices were discontinued and Asian Americans have been commonly (albeit misleading) referred to as the "model minority" in terms of academic performance. Yet, many have still not been fully incorporated into American society.

More recent groups have also faced the dilemma of incorporation into the U.S. mainstream society. The integration of these immigrant groups into American society is not as direct as previously suggested. Since 1965 , in particular, with the elimination of the U.S. immigration quota system, large numbers of immigrants have flocked to the U.S. from Central and South America, the Caribbean, Southeast Asia, and Africa. Unlike many of the earlier immigrants, these groups have been largely "of color" and have been faced with new patterns of incorporation into the stratified system of their host society. Therefore, old assumptions of assimilation and integration fail to address the unique processes of incorporation for these groups.

This change in U.S. immigration patterns has introduced the need to question traditional immigration and propose alternate explanations of incorporation into mainstream society. In their seminal work, Portes and Zhou (1993) addressed the particular assimilation patterns of post-1965 immigrants of color. Portes and Zhou (1993) argue that most post-1965 immigrants have come to the U.S. lacking the political 
and economic resources necessary for easy transition into mainstream society. As a result, these immigrants tend to settle in the poor areas of their racial counterparts here in the U.S. Thus, over time, immigrants of color assimilate to the segmented culture of their immediate surroundings, not that of middle class, mainstream America (Portes \& Zhou, 1993).

Indicative of this phenomenon are the experiences of second-generation Blacks, and particularly West-Indians, who report having been treated in most places as Black Americans until they point out their heritage. At that point, their treatment, particularly by White Americans changes, as mainstream America views Black immigrants as more hard-working than non-immigrant Black Americans. Consequently, many secondgeneration Black immigrants will try to retain some aspect of their parents' national identity, such as an accent, to separate themselves from non-immigrant Blacks (Portes \& Rumbaut, 2001).

In a 1994 study, Rumbaut investigated other social and cultural factors that influenced second-generation immigrants' assimilation to American society, and more specifically, their psychological development. For example, results from that study found second-generation girls to exhibit lower self-esteem and greater levels of parent-child conflict. The study also reported that being born in the United States increased the likelihood that second-generation students would identify themselves as American. Furthermore, Rumbaut (1994) found that community type significantly impacted secondgeneration students' ethnic self-identity. For example, second-generation students attending urban schools were more likely to adopt the identities of their peers, while students attending private schools were more likely to identify with the national identities 
of their parents, suggesting that socioeconomic status, does indeed, influence students' educational attitudes, beliefs and behaviors. This is a direct contradiction of Ogbu's (2003) argument that descendants of voluntary immigrant groups continue to be influenced by the attitudes, beliefs and behaviors of their forebears regardless of immigrant generation.

Despite these experiences, a longitudinal study conducted by Portes and Rumbaut (1996), found that second-generation Jamaican (70.3\%) and other West Indian (68.7\%) students exhibited higher percentages of school engagement than any other secondgeneration immigrant group in their study. Nonetheless, in a later study, more than half of the children of Black immigrants reported that they expected to be confronted with racial discrimination in their futures, despite having high academic achievement (Portes \& Rumbaut, 2001). Black immigrants (as well as Asians), due to their obvious racial identification, cannot easily voluntarily choose their own ethnic identification, which, in turn, proves to be a barrier to occupational mobility and social acceptance (Portes \& Rumbaut, 2001).

Explanations for the higher educational levels of second-generation students include parental educational levels, socioeconomic status (SES) and father's occupational attainment, (Portes \& Rumbaut, 1990). Contradictory to the Ogbu thesis, however, Portes and Rumbaut (1990) found that immigrant generation does not affect education. There is a general rise in average years of schooling from the first to the thirdgenerations; then, with the fourth generation, average schooling begins to decline, although this phenomenon is not significant (Portes \& Rumbaut, 1990). 


\section{Hypotheses}

An examination of the educational attainment of non-immigrant and immigrant Black students through the lens of the segmented assimilation theory suggests a possible alternative to Ogbu's cultural ecological theory of school performance. Therefore, the following hypotheses are generated to assess whether either perspective can be useful in advancing knowledge and understanding of Black students' academic performance:

1. Immigrant Black students differ from non-immigrant Black students in their attitudes toward reading (as measured by assessment scores on SATR);

2. Immigrant Black students differ from non-immigrant Black students in their perceptions of reading self-concept (as measured by assessments scores on SRSC);

3. Immigrant Black students differ from non-immigrant Black students in reading literacy (as measured by assessment scores on the PIRLS literacy exam);

4. Socio-cultural factors in the experiences of voluntary and involuntary minorities predict attitudes toward reading, reading self-concept and reading literacy achievement among non-immigrant and immigrant Black students.

\section{Summary}

This literature review examined research on the cultural-ecological theory of school performance (the Ogbu thesis) and segmented assimilation theory as they relate to the academic success or failure of Black students in the U.S. The review began with an overview of the state of research on the education of non-immigrant and immigrant Black students, followed by a discussion of Ogbu's classification schema that distinguishes between voluntary and involuntary minorities and each group's orientation toward education. Next, an integrative review of recent research on the academic performance 
of Black students in the context of the cultural-ecological theoretical perspective was undertaken. Finally, segmented assimilation theory as an alternative perspective from which to examine the academic success or failure of minority students was introduced, followed by the formulation of specific hypotheses to test in assessing the viability of these theoretical views. The next chapter details the methodology of the study. 


\section{CHAPTER III}

\section{METHODOLOGY}

Chapter 3 describes the methodology used in conducting the present study. I discuss the research design, population and sample selection, data collection procedures, measurement of variables, and statistical procedures developed to analyze the data in the chapter to follow.

\section{Research Design}

The present study used secondary, archived survey data obtained from the Progress in International Reading Literacy Study of 2001 (PIRLS) (Ogle et al., 2003), a large international comparative study of the reading literacy of young students conducted by the International Association for the Evaluation of Educational Achievement (IEA) under the auspices of the National Center for Education Statistics (NCES). PIRLS 2001 was the first in a planned 5-year cycle of international trend studies in reading literacy, which focused on the achievement and reading experiences of children in 35 countries in levels equivalent to fourth grade in the United States (Kastberg et al., 2004).

The primary purpose of PIRLS 2001 was to provide national comparative estimates on the reading literacy of fourth-graders and examine factors that may have been associated with the acquisition of reading literacy (Ogle et al., 2003). For the purpose of the present study, PIRLS 2001 data were used to test Ogbu's theory of cultural-ecological school performance through an examination of the relationship between immigrant status, socio-cultural influences, and reading achievement among non-immigrant and Black immigrant students in the United States. The study was able to accomplish this task using PIRLS data, which administered an assessment of reading 
comprehension and gathered information on students' reading behaviors through background questionnaires.

\section{Population and Sample Selection}

The PIRLS 2001 sample was drawn from a population that included students and their teachers who were separately surveyed. The student survey consisted of assessment items and a separately timed background questionnaire collecting basic demographic information and data on students' reading habits, classroom experiences, and attitudes about school. The teacher questionnaire, completed by teachers of the selected classrooms, was composed of demographic and background questions as well as questions about reading, instructional practices, and attitudes. There was also a school questionnaire, completed by the school principal or designate, which collected information on the demographic characteristics of the school and the structure and approach of education instruction (Kastberg et al., 2004). The present investigation only uses data from students.

PIRLS 2001 used a three-stage stratified cluster sample design to efficiently and accurately select samples of students within selected schools and classrooms. To derive student samples that permitted efficient and economical data collection, this design capitalized on the structure of the student population (i.e., students grouped in classes within schools) (Kastberg et al., 2004). The first step of this three-stage design sampled geographic units referred to as primary sampling units (PSUs) that were composed of metropolitan areas, a single county, or a group of contiguous counties. The second stage consisted of sampling at least 150 schools that were stratified by geographical characteristics (states, countries, etc.), school type (public or private) and level of 
urbanization (rural, urban or suburban). The third and final stage of the design consisted of selecting intact classrooms within schools. For each selected school agreeing to participate, a list of all fourth-grade classrooms within the school was compiled with one classroom selected at random from each participating school (Kastberg et al., 2004).

Furthermore, the PIRLS 2001 sampling design required that schools be sampled with a probability proportional to size and that classrooms be sampled with equal probabilities. To adjust for these differential selection probabilities and ensure proper survey estimates, PIRLS 2001 computed a sampling weight for each participating student. Because appropriate sampling weights are essential for the computation of accurate survey results, however, the ability to provide proper sampling weights is an essential requirement of an acceptable sample design. Therefore, a three-step procedure involving selection probabilities for schools, classrooms, and students sampling weights was used to calculate sampling weights (Martin, Mullis, \& Kennedy, 2003).

Private schools and schools with high enrollments of Black and Hispanic students were oversampled to increase the reliability of estimates for these groups. As done in many large-scale data collection efforts, NCES employed sampling weights based on principles of sampling theory to ensure that oversampling of groups that are underrepresented in the population does not affect inferences drawn from such oversampled groups. The basic sampling weight attached to each student record was the product of the three intermediate weights: the first stage (school) weight, the second stage (classroom) weight, and the third stage (student) weight. The first stage in calculating sampling weights consisted of computing a school weight. In the second stage, a classroom weight was calculated to reflect the probability of the sampled classroom(s) being selected from 
among all the classrooms in the school at the target grade level. In the third stage, a nonparticipation adjustment was made to compensate for students who did not take part in the testing. This was calculated independently for each sampled classroom (Martin et al., 2003).

Because of the complex sampling design, computing standard errors to quantify sampling variability becomes complicated. In order to compensate and correct for possible errors, PIRLS 2001 chose the jackknife repeated replication technique (JRR), because of its computational straightforwardness and because it provides approximate unbiased estimates of the sampling errors of means, totals, and percentages (Martin et al., 2003).

For the purpose of estimation of reading achievement, PIRLS 2001 used plausible values to obtain proficiency scores in reading for all students, even though each student responded to only a part of the assessment item pool. Specifically, this method of using plausible values ensured the accuracy of estimates of the proficiency distributions for the PIRLS population as a whole, and particularly for comparisons between subpopulations. For example, the variation between the five plausible values generated for each respondent reflected the uncertainty associated with proficiency estimates for individual respondents. For each of the PIRLS reading scales, item response theory (IRT) scaling procedure yielded five imputed scores or plausible values for every student in which the differences between the five values were very small.

Statistical analyses of item data were conducted to check for evidence of differences in student performance across countries that could indicate a translation problem. PIRLS also needed to develop procedures that would allow them to reliably 
evaluate student responses within and across countries. As a result, PIRLS arranged to have a sample of 200 students' responses to each item in each country scored independently by two readers. Scoring reliability across countries was, on average, more than 90 percent. PIRLS also employed a built-in Bonferroni correction for multiple comparisons.

Finally, estimates were computed for each of the PIRLS statistics, by using each of the five plausible values in turn, and the results were averaged to derive the reported value. Therefore, the standard errors that accompanied each reported statistic included two components: one quantifying sampling error and the other quantifying imputation error (Martin et al., 2003). The minimum and maximum possible test scores were 0 and 1000 , respectively, with an international average of 500 (Ogle et al., 2003).

The target population for PIRLS 2001 was all fourth-grade students in 35 countries including the United States. Within the U.S., schools in 33 states were selected to participate in the study, and the district office superintendent of each selected school was contacted for permission to include the schools. Selected private schools were contacted directly. Once schools agreed to participate, the PIRLS Within-Schools Sampling Software (W3S) was used to select the sample of students to participate in the assessment (Kastberg et al., 2004). The original U.S. PIRLS sample consisted of data from 200 schools ( 150 public and 50 private), which yielded a sample of 4,091 students. Private schools and schools with high enrollments of Black and Hispanic students were oversampled to increase the reliability of estimates for these groups. After replacing schools that refused to participate, 174 schools participated in the study. Students who were classified as functionally or mentally disabled and those who were unable to read or 
write in the language of the test were excluded from the study. After exclusions and absentees, a total of 3,763 students were assessed (Ogle et al., 2003).

In the present study, a sub-sample of U.S. students who identified themselves as Black ( $\mathrm{N}=525)$ was taken from the larger study. Within this category, students identified whether they were born in the U.S. $(n=364)$ or born in a country other than the U.S. $(n=161)$. Students were then recoded into the following categories: non-immigrant $(n=439)$, foreign-born immigrant $(n=39)$, and second-generation immigrant $(n=47)$. Nonimmigrant students were defined as those students who, along with their mothers, were born in the U.S. Students born in a country other than the U.S., but whose mothers were born in the U.S. were also defined as non-immigrant, since the data did not describe the circumstances of the birthplaces. Foreign-born students were identified as those students who, along with their mothers, were born in a country outside of the U.S. Finally, students who were born in the U.S., but whose mothers were born in a country other than the U.S., were classified as second-generation students.

\section{Data Collection Procedures}

Data for PIRLS 2001 were collected in the final months of the 2000-01 schoolyear. In the United States, data were collected in the spring of 2001 from both public and private schools. Data collected included students' responses from paper-and-pencil assessments as well as responses from background questionnaires completed by students, teachers, and school administrators. The paper-and-pencil assessments focused on three aspects of reading literacy: (a) purposes of reading, (b) processes of comprehension, and (c) reading behaviors and attitudes. Specifically, a written test of reading comprehension was administered to assess purposes of reading and processes of comprehension. 
Questions referring to purposes of reading were equally distributed between literary items and informational items. Processes of comprehension were assessed through multiplechoice and constructed-response questions that required students to construct meaning to different reading passages (Ogle et al., 2003).

Additionally, reading behaviors and attitudes were addressed by student background questionnaires. These questionnaires asked students about their attitudes toward reading, reading self-concept, reading habits, and aspects of their home environments that may influence reading literacy (Ogle et al., 2003). Based on PIRLS 2001, indexes to measure students' attitudes toward reading (SATR) and reading selfconcept (SRSC) were created and will be described more fully in the next section.

Data were also secured on a number of demographic variables such as ethnicity, gender, immigrant status and reading assessment, consisting of a test of reading literacy and questionnaires to collect information about fourth-grade children's reading literacy performance.

\section{Measurement of Variables}

\section{Dependent Variables}

Three major dependent variables were included in the present study: student attitudes toward reading (SATR), student reading self-concept (SRSC), and reading literacy. To measure student attitudes toward reading, an index was constructed (SATR) based on students' responses indicating their extent of agreement with five statements: (a) "I read only if I have to;" (b) "I like talking about books with other people;" (c) "I would be happy if someone gave me a book as a present;" (d) "I think reading is boring;" and (e) "I enjoy reading." A 4-point scale was used to measure responses to each of these 
statements: $1=$ Disagree a lot, $2=$ Disagree a little, $3=$ Agree a little, and $4=$ Agree a lot. Responses to negative statements ( 1 and 4 ) were reverse-coded. The SATR index was a summated scale score based on combining responses to the five items. Similarly, the students' reading self-concept index (SRSC) was operationalized using the procedure described above based on students' responses to four statements: (a) "Reading is very easy for me;" (b) "I do not read as well as other students in my class;" and (c) "Reading aloud is very hard for me." Reverse coding was used for responses to statements 2 and 3 in creating the summated score for the SRSC index. Reading literacy, the third dependent variable, was based on a standardized reading literacy test that was administered to each student. The test minimum and maximum possible test scores were 0 and 1000, respectively, with an international average of 500 (Ogle et al., 2003).

\section{Independent Variables}

Independent variables included in the present study were measured as follows: Immigrant status $-1=$ non-immigrant, $2=$ second-generation immigrant, and 3=foreignborn immigrant; sex $-1=$ female, $2=$ male. Socioeconomic status (SES) was measured by the following items: length of U.S. residence, parents' education, and number of books in the home (Portes \& Rumbaut, 1990). Length of U.S. residence is measured as follows: $1=$ whole life/born in the U.S., $2=$ nine or more years, $3=$ fewer than nine years.

Mother's and father's education are often difficult to compare in the same analysis because these variables tend to be highly correlated. To account for this phenomenon, some researchers have used the mean of father's and mother's years of education (Marks, McMillan, Jones, \& Ainley, 2000). Therefore, parents' education was operationalized as the mean of mother's and father's years of education. The variable 
was then recoded into the following categories: $1=$ less than high school graduate, $2=$ high school graduate, $3=$ some college or technical school, $4=$ college graduate.

Because it is not clear that fourth-graders are able to report family income accurately, PIRLS did not ask students to report family income, but rather, asked students to indicate their possession of a number of items that can be related to a family's economic circumstances including the number of books in the home (Martin et al., 2003). The number of books in the home is often used as a proxy for SES (Baker, Goesling, \& Letendre, 2002; Desimone, Smith, Baker, \& Ueno, 2005; Duncan \& Magnuson, 2005; Levitt \& Fryer, 2004; Smith, Brooks-Gunn, \& Klebanov, 1997; Tremblay, Ross, \& Berthelot, 2001) as it is often indicative of the home environment's contribution to academic resources and explains has been found to explain nearly one-third of the "poverty effect" (Duncan \& Magnuson, 2005; Smith, Brooks-Gunn, \& Klebanov, 1997). Number of books in the home was classified into one of the following categories: $1=0-10$ books, $2=11-25$ books, $3=26-100$ books, $4=101-200$ books, or $5=$ more than 200 books.

Behavioral/cultural characteristics were measured by amount of time spent reading for fun and amount of time spent watching television, as these are two of many activities through which cultural knowledge and beliefs are transmitted. For example, Portes and Rumbaut (2001) asserted that second-generation Hispanic students were more likely to be bilingual than some other second-generation students partly because of access to Spanish-speaking television. Conversely, amount of time spent watching television can differ across cultural norms. For example, reports from PIRLS 2001 stated that American students watch significantly more television than students from other countries (Ogle et al., 2003). Furthermore, in his ethnographic study in Shaker Heights, Ohio, 
Ogbu (2003) reported that Black students spent more time watching television and playing video games than did White students. Amount of time spent watching television can also be negatively associated with reading literacy achievement (Ogle et al., 2003). Amount of time spent watching television was classified into the following categories: $1=$ every day or almost every day, $2=$ once or twice a week, $3=$ twice a month or less. Amount of time spent reading for fun, on the other hand, can be positively associated with reading literacy achievement (Ogle et al., 2003). Amount of time spent reading for fun was reverse coded into the following: $1=$ twice a month or less, $2=$ once or twice a week, $3=$ every day or almost every day.

\section{Data Analysis}

In order to more accurately estimate sampling error, the International Association for the Evaluation of Educational Achievement (IEA) produced a statistical software, the IDB Analyzer, to apply in analyses using PIRLS data, which we employ instead of more conventional computer packages (e.g., SPSS). Univariate analyses were performed to provide descriptive information of the overall sample. Frequency distributions and percentages were reported for each of the independent variables (immigrant status, sex, background/socioeconomic status, and behavioral/cultural characteristics). After describing the sample, the main focus of the analysis was on employing PIRLS data to test the specific hypotheses developed to examine Ogbu and Simons' theory. Hypotheses 1, 2 and 3 were tested using bivariate correlation and analysis of variance (ANOVA), which compared mean scores for each of the three dependent variables (student attitudes toward reading [SATR], student reading self-concept [SRSC], and reading literacy achievement) by sex and immigrant status. 
Hypothesis 4 was tested using ordinary least squares (OLS) multiple regression. The order of the entry of seven independent variables was specified such that they comprise three models (see equations below). Informed by previous research, the models were: (a) immigrant status (non-immigrant and second-generation immigrant; with foreign-born immigrant serving as the reference group); (b) background/socioeconomic status (SES) (parents' education, number of books in the home, length of U.S. residence); (c) behavioral/cultural characteristics (amount of time spent watching television, amount of time spent reading for fun). For each dependent variable (SATR, SRSC, reading literacy achievement), regression analyses were performed to determine the relative magnitude of the relationship of each predictor variable with the dependent variables. The full model re-estimated immigrant status differences in SATR, SRSC and reading literacy achievement by controlling for the other predictor variables. Regression analyses for each model were conducted separately for girls and boys.

Model 1: Equation

$\mathrm{Y}=\alpha+\mathrm{B}_{1} \mathrm{X}_{1}+\mathrm{B}_{2} \mathrm{X}_{2}$

\{

Immigrant status predictors

Model 2: Equation

$\mathrm{Y}=\alpha+\mathrm{B}_{3} \mathrm{X}_{3}+\mathrm{B}_{4} \mathrm{X}_{4}+\mathrm{B}_{5} \mathrm{X}_{5}$

\{

Background/Socioeconomic status predictors

Model 3: Equation

$\mathrm{Y}=\alpha+\mathrm{B}_{6} \mathrm{X}_{6}+\mathrm{B}_{7} \mathrm{X}_{7}$

\{

Behavioral/Cultural characteristics predictors

Model 4: Equation

$\mathrm{Y}=\alpha+\mathrm{B}_{1} \mathrm{X}_{1}+\mathrm{B}_{2} \mathrm{X}_{2}+\ldots+\mathrm{B}_{3} \mathrm{X}_{3}+\mathrm{B}_{4} \mathrm{X}_{4}+\mathrm{B}_{5} \mathrm{X}_{5}+\ldots \ldots+\mathrm{B}_{6} \mathrm{X}_{6}+\mathrm{B}_{7} \mathrm{X}_{7}$

\{

Immigrant status

\}\{

Background/SES

Behavioral/Cultural (all predictors) 


\section{Summary}

This chapter has discussed the methods used in this study to test Obgu and Simons' (1998) cultural-ecological theory of school performance using data from the Progress in Reading Literacy Study of 2001 (PIRLS). The chapter began with a discussion of the research design of PIRLS and how the data are appropriate for the present study. Next, the chapter described the population and detailed how the sample was selected, followed by an explanation of the data collection procedures. The chapter also described the measurement of the independent and dependent variables (with supporting rationale). Lastly, the chapter described the statistical procedures that were used in the data analysis. The next chapter presents the results of the analysis and reports the study's findings. 


\section{CHAPTER IV}

\section{RESULTS}

Chapter 4 presents the results of the current study. I, first, provide a description of the sample and present a summary of the major variables included in the analysis. Secondly, results are presented based on the testing of hypotheses one, two, and three, which involve bivariate analyses of the relationship between Immigrant status (along with other factors) and each of the dependent variables (i.e., student attitudes toward reading, student reading self-concept, and reading literacy). Thirdly, the results for the test of hypothesis four are presented, focusing on the relationship between immigrant status and each of the three dependent variables, while simultaneously controlling for the other independent variables. All analyses are performed with findings reported separately for male and female students. Chapter 4 concludes with a summary of the study's main findings.

\section{Description of the Sample}

Table 1 describes the characteristics of the 525 participants in the study. As shown in Table 1, slightly more than half of the participants were girls $(54.1 \%)$. The majority of the sample consisted of non-immigrants (83.6\%), with fewer secondgeneration immigrants $(9.0 \%)$ and foreign-born immigrants $(7.4 \%)$. Furthermore, a majority of the participants have lived in the United States their whole lives (70.1\%), while $19.7 \%$ have lived in the U.S. for nine or more years, and $10.2 \%$ have lived in the U.S. for fewer than nine years.

A majority of the participants $(60.9 \%)$ indicated that their parents were college graduates and another $22.0 \%$ indicated that their parents had attended some college or 
technical school. Participants also reported the number of books in the home as follows: 10 or fewer books (15.6\%), $11-25$ books (26.4\%), $26-100$ books (28.7\%), $101-200$ books (14.1\%), and more than 200 books (15.0\%). A majority of participants reported that they watch television every day or almost every day $(69.3 \%)$, while nearly half (49.9\%) of participants, however, reported that they read for fun twice a month or less.

\section{Hypothesis 1}

Hypothesis 1 states that immigrant Black students differ from non-immigrant Black students in their attitudes toward reading (SATR). As shown in Table 2, mean scores for girls' attitudes toward reading range from 2.25 for second-generation immigrants to 2.32 for foreign-born immigrants. For boys, mean scores for attitudes toward reading range from 2.32 for foreign-born immigrants to 2.46 for secondgeneration immigrants. The differences in attitudes toward reading, however, are not significant, therefore, the hypothesis that immigrant students differ from non-immigrant students in their attitudes toward reading is not supported.

Hypothesis 2

Hypothesis 2 states that immigrant Black students differ from non-immigrant Black students in their perceptions of reading self-concept (SRSC). As shown in Table 3, mean scores for girls' reading self-concept range from 2.13 for foreign-born immigrants to 2.43 for non-immigrants. For boys, mean scores for reading self-concept range from 2.25 for foreign-born immigrants to 2.68 for second-generation immigrants. The differences in reading self-concept, however, are not significant, therefore, the hypothesis that immigrant students differ from non-immigrant students in their perceptions of reading self-concept is not supported. 
Table 1

Description of the Sample

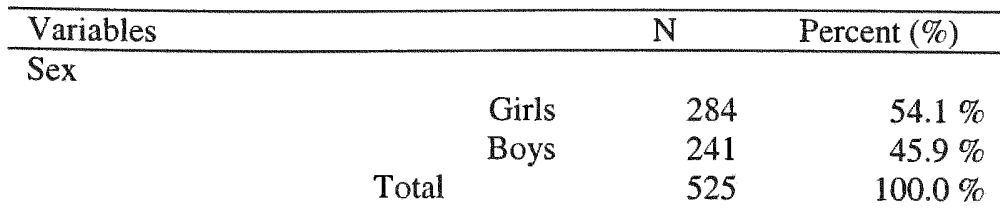

Immigrant Status

$\begin{array}{rrr}\text { Non-immigrant } & 439 & 83.6 \% \\ \text { Second-generation immigrant } & 47 & 9.0 \% \\ \text { Foreign-born immigrant } & 39 & 7.4 \% \\ \text { Total } & 525 & 100.0 \%\end{array}$

Family background/ SES

Length of U.S. residence

$\begin{array}{crr}\text { Whole life/ U.S. born } & 364 & 70.1 \% \\ 9 \text { or more years } & 102 & 19.7 \% \\ \text { Fewer than 9 years } & 53 & 10.2 \% \\ \text { Total } & 519 & 100.0 \%\end{array}$

Parents' Education

Less than high school

High school graduates

$\begin{array}{rr}23 & 6.3 \% \\ 39 & 10.7 \% \\ 80 & 22.1 \% \\ 221 & 60.9 \% \\ 363 & 100.0 \%\end{array}$

Number of books in the home

$\begin{array}{rrr}0-10 \text { books } & 82 & 15.8 \% \\ 11-25 \text { books } & 137 & 26.4 \% \\ 26-100 \text { books } & 149 & 28.7 \% \\ 101-200 \text { books } & 73 & 14.1 \% \\ \text { More than 200 books } & 78 & 15.0 \% \\ \text { Total } & 519 & 100.0 \%\end{array}$

Behavioral/ Cultural

How often watch TV

$\begin{array}{rrr}\text { Every day or almost every day } & 356 & 69.3 \% \\ \text { Once or twice a week } & 44 & 8.6 \% \\ \text { Twice a month or less } & 114 & 22.1 \% \\ \text { Total } & 514 & 100.0 \%\end{array}$

How often read for fun

\begin{tabular}{ccc} 
Every day or almost every day & 155 & $30.3 \%$ \\
Once or twice a week & 101 & $19.8 \%$ \\
Twice a month or less & 255 & $49.9 \%$ \\
Total & 511 & $100 \%$ \\
\hline
\end{tabular}


Table 2

Mean Statistics for Student Attitudes Toward Reading (SATR) by Sex and Immigrant Status

\begin{tabular}{|c|c|c|c|c|c|c|c|c|c|c|c|c|}
\hline & \multicolumn{6}{|c|}{ Girls } & \multicolumn{6}{|c|}{ Boys } \\
\hline & \multicolumn{2}{|c|}{$\begin{array}{c}\text { Non- } \\
\text { Immigrant } \\
(\mathrm{N}=193)\end{array}$} & \multicolumn{2}{|c|}{$\begin{array}{c}\text { Second } \\
\text { Generation } \\
(N=31)\end{array}$} & \multicolumn{2}{|c|}{$\begin{array}{c}\text { Foreign } \\
\text { Born } \\
(\mathrm{N}=21)\end{array}$} & \multicolumn{2}{|c|}{$\begin{array}{c}\text { Non- } \\
\text { Immigrant } \\
(\mathrm{N}=168)\end{array}$} & \multicolumn{2}{|c|}{$\begin{array}{c}\text { Second } \\
\text { Generation } \\
(\mathrm{N}=16)\end{array}$} & \multicolumn{2}{|c|}{$\begin{array}{c}\text { Foreign } \\
\text { Born } \\
(\mathrm{N}=16)\end{array}$} \\
\hline & $M$ & $S D$ & $M$ & $S D$ & $M$ & $S D$ & $M$ & $S D$ & $M$ & $S D$ & $M$ & $S D$ \\
\hline $\begin{array}{l}\text { Student } \\
\text { Attitudes } \\
\text { Toward } \\
\text { Reading } \\
\end{array}$ & 2.26 & .54 & 2.25 & .40 & 2.32 & .40 & 2.36 & .62 & 2.46 & .52 & 2.32 & .53 \\
\hline
\end{tabular}

Table 3

Mean Statistics for Student Reading Self-Concept (SRSC) by Sex and Immigrant Status

\begin{tabular}{|c|c|c|c|c|c|c|c|c|c|c|c|c|}
\hline & \multicolumn{6}{|c|}{ Girls } & \multicolumn{6}{|c|}{ Boys } \\
\hline & \multicolumn{2}{|c|}{$\begin{array}{c}\text { Non } \\
\text { Immigrant } \\
(\mathrm{N}=193)\end{array}$} & \multicolumn{2}{|c|}{$\begin{array}{c}\text { Second } \\
\text { Generation } \\
(\mathrm{N}=31)\end{array}$} & \multicolumn{2}{|c|}{$\begin{array}{l}\text { Foreign } \\
\text { Born } \\
(\mathrm{N}=21)\end{array}$} & \multicolumn{2}{|c|}{$\begin{array}{c}\text { Non- } \\
\text { Immigrant } \\
(\mathrm{N}=168)\end{array}$} & \multicolumn{2}{|c|}{$\begin{array}{c}\text { Second } \\
\text { Generation } \\
(\mathrm{N}=16)\end{array}$} & \multicolumn{2}{|c|}{$\begin{array}{c}\text { Foreign } \\
\text { Born } \\
(\mathrm{N}=16)\end{array}$} \\
\hline & $M$ & $S D$ & $M$ & $S D$ & $M$ & $S D$ & $M$ & $S D$ & $M$ & $S D$ & $M$ & $S D$ \\
\hline $\begin{array}{l}\text { Student } \\
\text { Reading } \\
\text { Self- } \\
\text { Concept }\end{array}$ & 2.43 & .66 & 2.32 & .57 & 2.13 & .71 & 2.44 & .63 & 2.68 & .66 & 2.25 & .54 \\
\hline
\end{tabular}




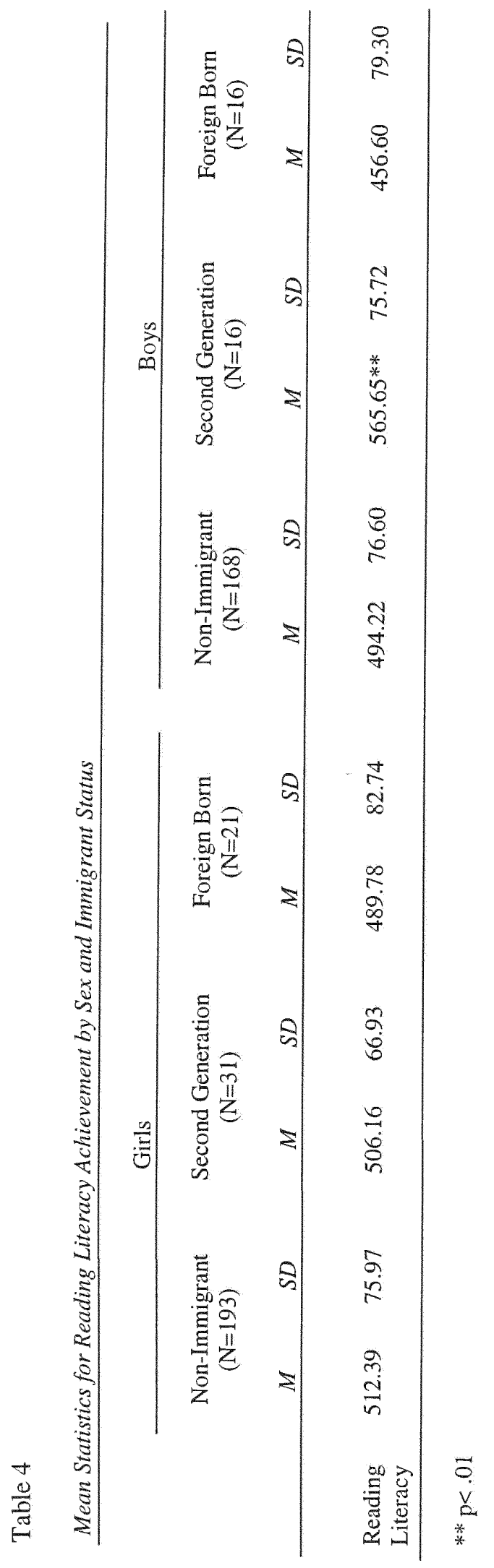




\section{Hypothesis 3}

Hypothesis 3 states that immigrant Black students differ from non-immigrant Black students in reading literacy as measured by assessment scores on the PIRLS literacy exam. Table 4 shows that mean reading literacy scores foreign-born girls mean reading literacy scores $(\mathrm{M}=489.78, \mathrm{SD}=82.74)$ are lower than those of second-generation girls $(M=506.16, S D=66.93)$ and non-immigrant girls $(M=512.39, S D=75.97)$. These differences in mean literacy scores, however, are not significant. For second-generation boys, mean reading literacy scores $(M=565.65, \mathrm{SD}=75.72)$ are higher than those of both foreign-born boys $(M=456.60, S D=79.30)$ and non-immigrant boys $(M=494.22$, $\mathrm{SD}=76.60$ ). The test for boys was significant, $\mathrm{F}(238)=6.589, \mathrm{p}<.01$. Therefore, the hypothesis that immigrant Black students differ from non-immigrant Black students in reading literacy is partially supported.

\section{Hypothesis 4}

Hypothesis 4 states that socio-cultural factors in the experiences of voluntary and involuntary minorities predict attitudes toward reading, reading self-concept and reading literacy achievement among non-immigrant and immigrant Black students. Table 5 shows the intercorrelations among all variables in the analysis, presented separately for girls (below the diagonal) and boys (above the diagonal). The intercorrelations reveal significant positive correlations between parents' education and reading achievement $(\mathrm{r}=.187)$, reading self-concept and reading achievement $(\mathrm{r}=.311)$, and how often they read for fun and reading achievement $(r=.254)$ for girls. Length of U.S. residence $(r=-.236)$ and how often they watch TV ( $r=-.142)$ were negatively and significantly associated with reading achievement for girls. 
Similar to girls, parents' education $(r=.169)$ and reading self-concept $(r=.286)$ were positively and significantly associated with reading achievement for boys. Also similar to girls, length of U.S. residence $(r=-.202)$ and how often they watch TV $(r=-.255)$ were negatively and significantly associated with reading achievement for boys. In contrast to girls, however, number of books in the home ( $r=140)$ and being a secondgeneration immigrant $(r=.202)$ were positively and significantly associated with reading achievement for boys. Also, being a foreign-born immigrant ( $r=-.151)$ was negatively and significantly associated with reading achievement for boys.

\section{Student Attitudes Toward Reading}

Table 6 shows the regression results for the following predictors of attitudes toward reading: immigrant status, background/ socioeconomic status, and behavioral characteristics, with separate analyses for girls and boys. Since the analysis strategy involves comparisons and parallel analyses for girls and boys, unstandardized regression coefficients are reported to facilitate such comparisons. The first equation (Model 1) in Table 6 is based on girls and regresses student attitudes toward reading (SATR) on dummy variables representing two of the three immigrant statuses, with foreign-born immigrants serving as the reference category. The second equation (Model 2) is based on girls and regresses SATR on background/SES variables represented by parents' education, number of books in the home, and length of U.S. residence. The third equation (Model 3) in Table 6 is based on girls and regresses SATR on behavioral/cultural characteristics represented by how much time is spent watching television and reading for fun. The fourth equation (Full Model), based on girls, re-estimates immigrant status 
differences in SATR controlling for the other explanatory variables. The next four equations in Table 6 present parallel equations for boys.

The regression coefficient for each independent variable assesses the relationship between that independent variable and the dependent variable while simultaneously holding constant other independent variables in that equation. Thus, these coefficients are partial regression coefficients which assess the partial relationships between the independent and dependent variables. As shown in Table 6, for girls (lower left panel), amount of time spent watching television (Model 3) has a negative and significant relationship to girls' attitudes toward reading $(b=-.12 ; p<.001)$. Amount of time reading for fun also has a negative and significant relationship to girls' attitudes toward reading $(\mathrm{b}=-.10 ; \mathrm{p}<.01)$. The relationship to amount of time watching television continues to persist after all of the predictors are included in the equation (Model $4 ; \mathrm{b}=-.13, \mathrm{p}<.001$ ), however, the magnitude of the relationship between amount of time reading for fun and girls' attitude toward reading weakens and is no longer significant in the full model (Model 4).

Similarly, for boys, Table 6 (lower right panel) shows that the amount of time spent watching television has a negative and significant relationship to attitudes toward reading (Model 3; $b=-.10, p<.05$ ), which continues to persist in the full model $(b=-.13$, $\mathrm{p}<.01)$. Immigrant status and background/SES are not significant predictors of student attitudes toward reading (SATR) for girls or boys. 


\section{Student Reading Self-Concept}

Table 7 shows the regression regression results for the following predictors of student reading self-concept: immigrant status, background/ socioeconomic status, and behavioral characteristics. Again, analyses are performed separately for girls and boys. For girls, the first equation in Table 7 (Model 1) regresses student reading self-concept (SRSC) on dummy variables representing two of the three immigrant statuses, with foreign-born immigrants serving as the reference category. The second equation (Model 2) regresses SRSC on background/SES variables represented by parents' education, number of books in the home, and length of U.S. residence. The third equation (Model 3) regresses SRSC on behavioral/cultural characteristics represented by how much time is spent watching television and reading for fun. The fourth equation, based on girls, reestimates immigrant status differences in SRSC controlling for all of the predictor/explanatory variables. This analysis is repeated for boys.

As the results for girls show (left panel in Table 7), number of books in the home $(b=.06 ; \mathrm{p}<.05)$ and length of U.S. residence $(\mathrm{b}=.21 ; \mathrm{p}<.05)$ are positively and significantly related to girls' reading self-concept (Model 2). Also, for girls, amount of time reading for fun is positively and significantly related to girls' reading self-concept $(b=.08 ; p<.05)$ (Model 3). Length of U.S. residence continues to be a positive, significant predictor $(b=.23, p<.01)$ for girls in the full model (Model 4$)$, while the relationship to number of books in the home and the amount of time spent reading for fun do not continue to be significant after all of the predictors are included in the equation. In contrast, none of the predictors significantly affect reading self-concept of boys. 


\section{Reading Literacy Achievement}

Table 8 presents the regression results for the following predictors of reading literacy achievement: immigrant status, background/ socioeconomic status, and behavioral characteristics, with separate analyses for girls and boys. The left panel of Table 8 presents results for girls, while the right panel presents results for boys. The first equation in Table 8 regresses reading literacy achievement on dummy variables representing two of the three immigrant statuses, with foreign-born immigrants serving as the reference category. The second equation regresses reading literacy achievement on background/SES variables represented by parents' education, number of books in the home, and length of U.S. residence. The third equation in Table 8 regresses reading literacy achievement on behavioral/cultural characteristics represented by how much time is spent watching television and reading for fun. The fourth equation, based on girls, reestimates immigrant status differences in reading literacy achievement controlling for the other explanatory variables. The next four equations in Table 8 (right panel) present parallel analyses for boys.

As shown in Table 8, for girls, parents' education $(b=10.20 ; p<.01)$ and length of U.S. residence $(b=29.91 ; p<.05)$ are positively and significantly related to girls' reading literacy achievement (Model 2). The amount of time reading for fun (Model 3) is also a positive and significant predictor of girls' reading literacy achievement $(b=20.35$; $\mathrm{p}<.001$ ). In the full model, each of the three predictors continue to have a positive, significant relationship to girls' reading literacy achievement (parents' education, $\mathrm{b}=10.39 \mathrm{p}<.01$; length of U.S. residence, $\mathrm{b}=50.13, \mathrm{p}<.001$; amount of time reading for fun, $b=18.19 ; \mathrm{p}<.001)$. 
As shown in the right panel of Table 8 , among boys, being a second-generation immigrant (Model 1) is a positive and significant predictor of reading literacy achievement $(b=109.05 ; p<.01)$. In model 2 , length of U.S. residence has a positive and significant relationship to boys' reading literacy achievement $(b=23.66 ; p<.05)$. Model 3 shows that amount of time spent watching television has a negative and significant relationship to boys' reading literacy achievement $(b=-20.03 ; p<.01)$. In the full model for boys, the only predictor that continues to have a significant relationship to reading literacy achievement relative to other predictors is being a second-generation immigrant, $(b=71.54 ; p<.05)$.

\section{Summary}

This chapter presented the results of the current study. The chapter first provided a description of the sample with a presentation of summaries and tables. Next I presented findings based on tests of each of the four hypotheses. Hypothesis one, which states that immigrant Black students differ from non-immigrant Black students in their attitudes toward reading (SATR) was not supported. The second hypothesis that immigrant Black students differ from non-immigrant Black students in their perceptions of reading selfconcept (SRSC) was also not supported. Hypothesis 3, which states that immigrant Black students differ from non-immigrant Black students in reading literacy as measured by assessment scores on the PIRLS literacy exam was partially supported, as secondgeneration boys scored significantly higher than non-immigrant or foreign-born immigrant boys, but no significant differences were found among girls. The fourth, and final, hypothesis that socio-cultural factors in the experiences of voluntary and involuntary minorities predict attitudes toward reading, reading self-concept and reading 
literacy achievement among non-immigrant and immigrant Black students was supported. Behavioral/cultural characteristics were significant predictors of student attitudes toward reading (SATR) for girls and boys. For girls, number of books in the home and length of U.S. residence had a significant, positive relationship to reading self-concept (SRSC). There were no significant predictors of reading self-concept for boys. Parents' education, length of U.S. residence, and amount of time spent reading for fun were significant, positive predictors for girls' reading literacy achievement. For boys, being a secondgeneration immigrant has a significant, positive relationship to reading literacy achievement.

The next chapter (5) provides interpretation and discussion of the findings and examines implications of these results for advancing theoretical understanding and educational policy, followed by this study's overall conclusions and suggestions for future research. 


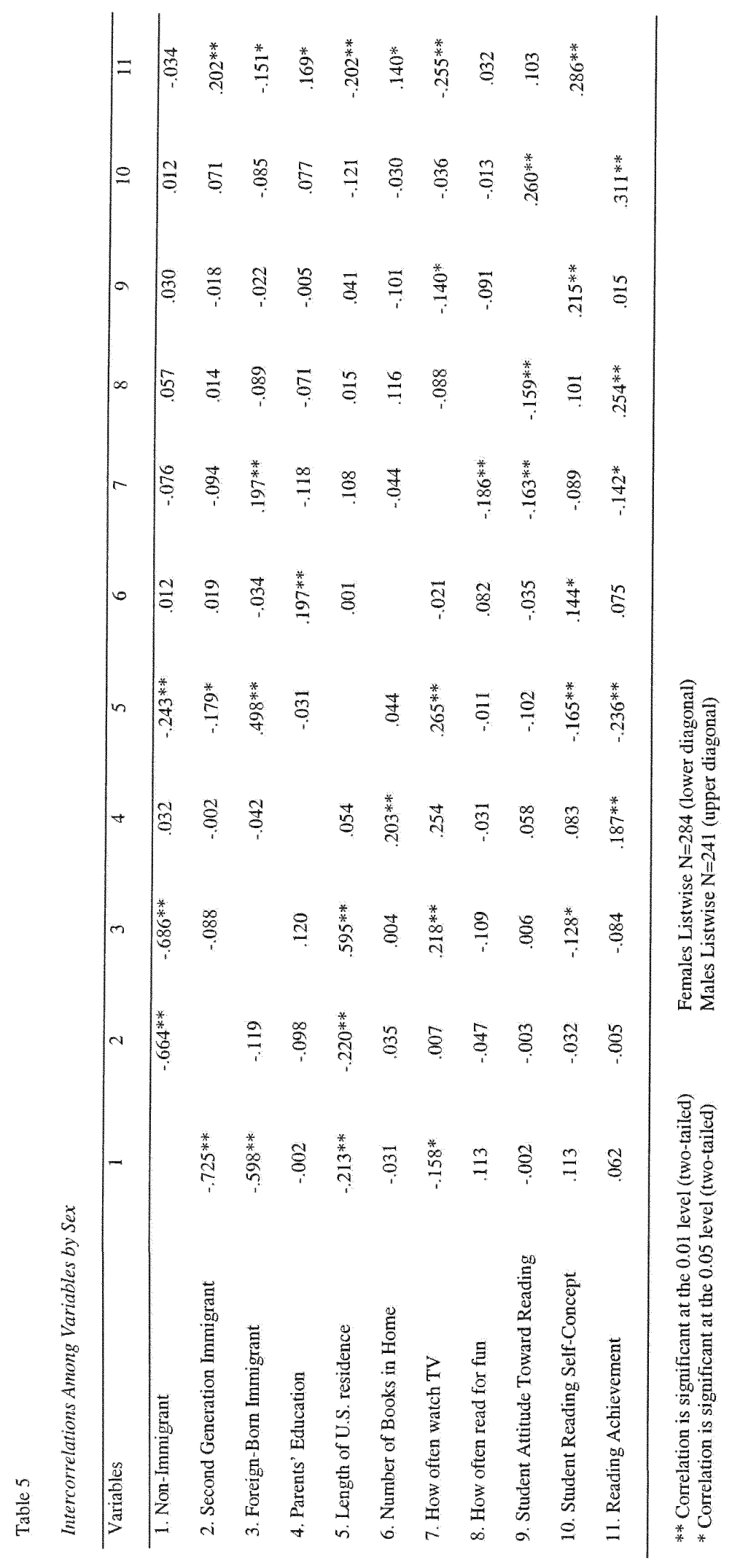

6 
Table 6

OLS Coefficients for Regression of Student Attitudes Toward Reading (SATR) on Immigrant

Status, Background/Socioeconomic Status (SES), and Behavioral/Cultural Characteristics by Sex

\begin{tabular}{|c|c|c|c|c|c|c|c|c|}
\hline \multirow{3}{*}{$\begin{array}{l}\text { Independent } \\
\text { Variable }\end{array}$} & \multicolumn{4}{|c|}{ GIRLS } & \multicolumn{4}{|c|}{ BOYS } \\
\hline & \multicolumn{4}{|c|}{ MODELS } & \multicolumn{4}{|c|}{ MODELS } \\
\hline & 1 & 2 & 3 & 4 & 1 & 2 & 3 & 4 \\
\hline \multicolumn{9}{|l|}{ Immigrant Status } \\
\hline Non-Immigrant & $\begin{array}{c}. .05 \\
(.08)\end{array}$ & & & $\begin{array}{l}.12 \\
(.22)\end{array}$ & $\begin{array}{l}.04 \\
(.20)\end{array}$ & & & $\begin{array}{l}.12 \\
(.22)\end{array}$ \\
\hline $\begin{array}{r}\text { Second } \\
\text { Generation }\end{array}$ & $\begin{array}{c}. .07 \\
(.09)\end{array}$ & & & $\begin{array}{l}.11 \\
(.24)\end{array}$ & $\begin{array}{l}.14 \\
(.24)\end{array}$ & & & $\begin{array}{l}.11 \\
(.24)\end{array}$ \\
\hline Foreign Born & \multicolumn{4}{|c|}{ Reference } & \multicolumn{4}{|c|}{ Reference } \\
\hline \multicolumn{9}{|l|}{ Background/SES } \\
\hline Books in Home & & $\begin{array}{c}.02 \\
(.02)\end{array}$ & & $\begin{array}{l}.01 \\
(.02)\end{array}$ & & $\begin{array}{l}-.07 \\
(.05)\end{array}$ & & $\begin{array}{l}-.08 \\
(.05)\end{array}$ \\
\hline $\begin{array}{r}\text { Parents' } \\
\text { Education }\end{array}$ & & $\begin{array}{l}.02 \\
(.03)\end{array}$ & & $\begin{array}{l}.02 \\
(.03)\end{array}$ & & $\begin{array}{c}.02 \\
(.04)\end{array}$ & & $\begin{array}{c}.02 \\
(.04)\end{array}$ \\
\hline $\begin{array}{l}\text { Length of U.S. } \\
\text { Residence }\end{array}$ & & $\begin{array}{c}.07 \\
(.06)\end{array}$ & & $\begin{array}{c}.04 \\
(.11)\end{array}$ & & $\begin{array}{c}.05 \\
(.07)\end{array}$ & & $\begin{array}{c}.05 \\
(.10)\end{array}$ \\
\hline
\end{tabular}

Behavioral/

Cultural

Watching TV

Reading for fun

$\begin{array}{cc}-.12 * * * & -.13 * * * \\ (.03) & (.03) \\ -.10^{* *} & -.03 \\ (.03) & (.04)\end{array}$

$2.32 \quad 2.23$

2.67

.06

274

Number of Cases

$.00 \quad .01$

$245 \quad 208$

$* \mathrm{p}<.05^{* *} \mathrm{p}<.01 * * * \mathrm{p}<.001$ (two-tailed tests)

Note: Numbers in parentheses are standard errors
11

.05

\begin{tabular}{lcccccccc} 
Constant & 2.32 & 2.23 & 2.67 & 2.19 & 2.32 & 2.37 & 2.62 & 2.76 \\
R2 & .00 & .01 & .06 & .05 & .00 & .02 & .03 & .07 \\
Number of Cases & 245 & 208 & 274 & 182 & 201 & 182 & 230 & 158 \\
\hline$* \mathrm{p}<.05^{* *} \mathrm{p}<.01 * * * \mathrm{p}<.001$ (two-tailed tests)
\end{tabular}


Table 7

OLS Coefficients for Regression of Student Reading Self-Concept (SRSC) on Immigrant Status,

Background/Socioeconomic Status (SES), and Behavioral/Cultural Characteristics by Sex

\begin{tabular}{|c|c|c|c|c|c|c|c|c|}
\hline \multirow{3}{*}{$\begin{array}{l}\text { Independent } \\
\text { Variable }\end{array}$} & \multicolumn{4}{|c|}{ GIRLS } & \multicolumn{4}{|c|}{ BOYS } \\
\hline & \multicolumn{4}{|c|}{ MODELS } & \multicolumn{4}{|c|}{ MODELS } \\
\hline & 1 & 2 & 3 & 4 & 1 & 2 & 3 & 4 \\
\hline \multicolumn{9}{|l|}{$\begin{array}{l}\text { Immigrant } \\
\text { Status }\end{array}$} \\
\hline Non-Immigrant & $\begin{array}{l}.30 \\
(.26)\end{array}$ & & & $\begin{array}{l}-.01 \\
(.35)\end{array}$ & $\begin{array}{l}.19 \\
(.17)\end{array}$ & & & $\begin{array}{l}-.01 \\
(.23)\end{array}$ \\
\hline $\begin{array}{r}\text { Second } \\
\text { Generation }\end{array}$ & $\begin{array}{l}.18 \\
(.27)\end{array}$ & & & $\begin{array}{l}-.28 \\
(.35)\end{array}$ & $\begin{array}{c}.43 \\
(.26)\end{array}$ & & & $\begin{array}{l}.19 \\
(.38)\end{array}$ \\
\hline Foreign Born & \multicolumn{4}{|c|}{ Reference } & \multicolumn{4}{|c|}{ Reference } \\
\hline \multicolumn{9}{|l|}{$\begin{array}{l}\text { Background/ } \\
\text { SES }\end{array}$} \\
\hline Books in Home & & $\begin{array}{l}.06^{*} \\
(.03)\end{array}$ & & $\begin{array}{c}.06 \\
(.04)\end{array}$ & & $\begin{array}{l}-.06 \\
(.03)\end{array}$ & & $\begin{array}{l}-.03 \\
(.03)\end{array}$ \\
\hline $\begin{array}{c}\text { Parents' } \\
\text { Education }\end{array}$ & & $\begin{array}{l}.05 \\
(.03)\end{array}$ & & $\begin{array}{l}.05 \\
(.03)\end{array}$ & & $\begin{array}{l}.05 \\
(.03)\end{array}$ & & $\begin{array}{l}.05 \\
(.03)\end{array}$ \\
\hline $\begin{array}{l}\text { Length of U.S. } \\
\text { Residence }\end{array}$ & & $\begin{array}{l}.21 * * \\
(.08)\end{array}$ & & $\begin{array}{l}.23^{* *} \\
(.07)\end{array}$ & & $\begin{array}{c}.09 \\
(.06)\end{array}$ & & $\begin{array}{c}.11 \\
(.09)\end{array}$ \\
\hline
\end{tabular}

Behavioral/

Cultural

Watching TV

$\begin{array}{ll}-.04 & -.01 \\ (.06) & (.07)\end{array}$

$-.03 \quad .05$
$-.04)$

$(.06) \quad(.07)$

(.04) (.05)

Reading for fun

$\begin{array}{cc}.08 * & .08 \\ (.04) & (.05)\end{array}$

$.01 \quad .01$

(.05) (.06)

Constant

$\begin{array}{llll}2.13 & 2.25 & 2.34 & 2.19\end{array}$

2.25

2.43

2.43

2.33

R2

$\begin{array}{llll}.02 & .07 & .02 & .09\end{array}$

.02

.03

.00

.04

Number of

$245 \quad 209$

275

182

201

182

230

158

$* \mathrm{p}<.05 * * \mathrm{p}<.01 * * * \mathrm{p}<.001$ (two-tailed tests)

Note: Numbers in parentheses are standard errors 


\section{Table 8}

OLS Coefficients for Regression of Reading Achievement on Immigrant Status, Background/Socioeconomic Status (SES), and Behavioral/Cultural Characteristics by Sex

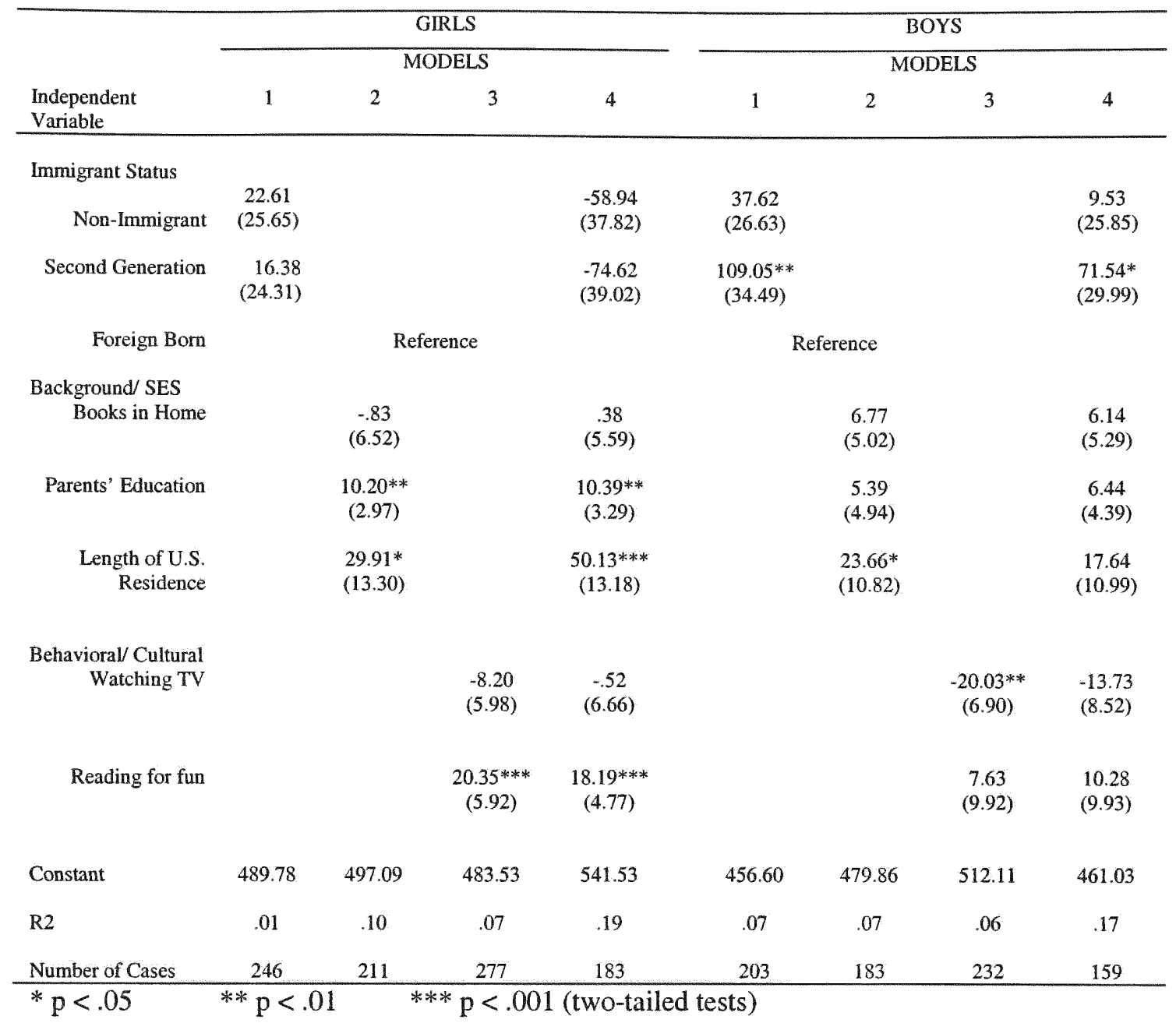

Note: Numbers in parentheses are standard errors 


\section{CHAPTER V}

\section{DISCUSSION AND CONCLUSIONS}

This final chapter of the dissertation provides interpretation and discussion of the findings and examines implications of these results for advancing theoretical understanding and educational policy, followed by this study's overall conclusions and suggestions for future research.

As stated in chapter 1, the purpose of the present study was to test Ogbu's Cultural-Ecological Theory of School Performance. One of the primary tenets of the Ogbu thesis is that Black immigrant students (mostly of West-Indian heritage) outperform their non-immigrant (mostly African-American) counterparts and that these differences in academic success can be accounted for by cultural factors that shape differences in commitment to education in West Indian and African American Black families. Yet, evidence to support this major proposition of Ogbu's theory had been drawn primarily from qualitative rather than quantitative data and without directly comparing Black students from immigrant and non-immigrant families. Therefore, a primary aim of the present study was to address these shortcomings through direct comparisons between Black immigrant students in the U.S. (both first and second generation) and their non-immigrant counterparts drawing upon data from a large-scale international study to examine students' perceptions and commitment to education by focusing on reading literacy. Reading performance was used as a measure of academic achievement because reading is the foundation for learning across all subjects and can be used for recreation and personal growth, as well as to prepare children to fully participate in the larger society (Ogle et al., 2003). Previous reports indicated that Black students 
scored significantly lower than White students on reading literacy assessments (Ogle et al., 2003). However, such reports had not compared the performance of non-immigrant Black students with immigrant Blacks.

The present study was also intended to examine the educational attainment of non-immigrant and immigrant Black students through the lens of the segmented assimilation theory (Portes \& Rumbaut, 1990, 2001; Portes \& Zhou, 1993) as a possible alternative to Ogbu's cultural ecological theory of school performance. This perspective argues that most post-1965 immigrants come to the U.S. lacking the political and economic resources necessary for easy transition into mainstream society. These immigrants also tend to be largely of color, and as a result tend to settle in the poor areas of their racial counterparts. Thus, over time, immigrants of color assimilate to the segmented culture of their immediate communities, not that of middle class, mainstream America (Portes \& Zhou, 1993).

Data from the Progress in International Reading Literacy Study of 2001 (PIRLS) were used in the present study. PIRLS 2001 was a large, international comparative study of the reading literacy of young students that focused on the achievement and reading experiences of children in 35 countries in grades equivalent to fourth grade in the United States. Data were secured on a number of variables that tapped into the psycho-social development of participants, including attitudes toward reading, reading self-concept, and demographic variables, such as ethnicity, gender, and immigrant status. Reading achievement was measured based on a written test of reading comprehension. Despite being conducted by the International Association for the Evaluation of Educational Achievement (IEA), few studies have examined reading literacy using PIRLS and none 
have specifically examined the reading performance of non-immigrant and immigrant Black students in the United States.

A sub-sample of U.S. students who identified themselves as Black was taken from the larger study. Within this category, students identified whether they were born in the U.S. or born in a country other than the U.S. Students were then categorized as nonimmigrant, foreign-born immigrant, and second-generation immigrant based on whether, along with their mothers, they were born in the U.S.

Data analysis consisted of descriptive statistics for an overall picture of the sample. Analysis of variance (ANOVA) was used to compare mean scores of each dependent variable: student attitudes toward reading (SATR), student reading selfconcept (SRSC), and reading literacy achievement by immigrant status and sex. Furthermore, multivariate analyses were conducted by using hierarchical ordinary least squares (OLS) regression to determine the magnitude of the relationship of each independent variable to the dependent variables: SATR, SRSC, and reading literacy achievement.

Four hypotheses were generated and tested to assess whether Ogbu's Cultural Ecological Theory of School performance or the segmented assimilation theory is useful in advancing knowledge and understanding of Black students' academic performance. The first hypothesis stated that immigrant Black students differ from non-immigrant Black students in their attitudes toward reading (SATR). Findings from the present study, however, found that immigrant and non-immigrant students did not differ in their attitudes toward reading. The second hypothesis that immigrant Black students differ from non-immigrant Black students in their perceptions of reading self-concept (SRSC) 
was also not supported. These findings, therefore, do not lend support to the tenets of the Ogbu thesis that assert that non-immigrant Black students develop ambivalent and contradictory attitudes toward schooling. Rather, findings of these two hypotheses are more in line with Portes and Rumbaut's (1990) theory that immigrants of color assimilate to the segmented culture of their immediate surroundings.

Hypothesis 3, which stated that immigrant Black students differ from nonimmigrant Black students in reading literacy as measured by assessment scores on the PIRLS literacy exam, was partially supported. Second-generation boys scored significantly higher than non-immigrant or foreign-born immigrant boys, but no significant differences were found among girls. This finding, therefore, lends only partial support to Ogbu's assertion that immigrant Black students perform better academically than do non-immigrant Black students. Portes and Rumbaut (2001) offer an alternative explanation in that many second- generation Black immigrants will try to retain some aspect of their parents' national identity, such as an accent, to separate themselves from non-immigrant Blacks. Still, according to Portes and Rumbaut (2001), Black immigrants, cannot voluntarily choose their own ethnic identification, due to their obvious racial identification. This can serve as a barrier to occupational mobility and social acceptance (Portes \& Rumbaut, 2001). Furthermore, there is a general rise in average years of schooling from the first to the third-generations; then, with the fourth generation, average schooling begins to decline (Portes \& Rumbaut, 2001).

The fourth, and final, hypothesis stated that socio-cultural factors in the experiences of voluntary and involuntary minorities predict attitudes toward reading, reading self-concept and reading literacy achievement among non-immigrant and 
immigrant Black students was supported. Behavioral/cultural characteristics were significant predictors of student attitudes toward reading (SATR) for girls and boys. For girls, number of books in the home and length of U.S. residence had a significant, positive relationship to reading self-concept (SRSC). This finding supports Rumbaut's (1994) finding that second-generation girls tend to exhibit lower self-esteem. None of the predictors were significant for reading self-concept among boys. Parents' education, length of U.S. residence, and amount of time students spent reading for fun were significant, positive predictors of girls' reading literacy achievement. Among boys, being a second-generation immigrant had a significant, positive relationship to reading literacy achievement. Again, the Ogbu thesis was only partially supported. Being a secondgeneration immigrant had a significant, positive relationship to boys' reading literacy achievement, but this did not hold true for girls. For girls, even though there were no significant differences in reading literacy achievement scores, socioeconomic factors and behavioral/cultural characteristics were significant predictors in their achievement. This is a direct contradiction of Ogbu's (1991) rejection of parents' education and other socioeconomic indicators as significant factors in non-immigrant Black students' school performance. Rather, findings related to this hypothesis tend to support Rumbaut's (1994) and Portes and Rumbaut's (2001) explanation for the higher educational levels of second-generation students being more influenced by parental educational levels and other indicators of social status.

The present study addressed contradictions in previous studies that have tested tenets of the Ogbu thesis. For example, as evident from previous research (AinsworthDarnell and Downey, 2002; Ford \& Harris, 1996; Harris, 2006; Roscigno \& Ainsworth- 
Darnell, 1999; Tyson, 2002), there were inconsistencies in the findings related to Black student academic achievement and oppositional identity, suggesting that there may be other factors which account for the academic success or failure of Black students. Findings from the present study lend support to previous studies (Ainsworth-Darnell and Downey, 2002; Ford \& Harris, 1996; Harris, 2006; Roscigno \& Ainsworth-Darnell, 1999; Tyson, 2002) that have refuted Ogbu's assertion that non-immigrant Black students develop an oppositional identity towards schooling. As found in these studies, behavioral characteristics and socioeconomic status are more closely associated with school performance than immigrant status. Furthermore, these studies failed to make direct comparisons between non-immigrant and immigrant Black students. When such comparisons were made, even though in some cases the immigrant students tried to maintain a separate identity from the non-immigrant Blacks, the dominant group often did not see such differences and over time the differences became less evident. Therefore, a need for an alternative explanation of the differential academic performance of immigrant and non-immigrant Black students is clearly evident. The results of the present study, which support Rumbaut's (1994) and Portes and Rumbaut's (2001) explanation, clearly imply that the higher educational levels of second-generation students are influenced by parental educational levels and other socioeconomic indicators. However, unlike previous research, findings from the present analysis produced empirical evidence to support this explanation through an appropriately designed study making direct comparisons of immigrant and non-immigrant youth.

The present study also lends partial support to previous studies that found higher academic achievement among second-generation immigrants (Bashi \& McDaniel, 1997; 
Butcher, 1994; Dodoo, 1997; Kao \& Tienda, 1995; Omi \& Winant, 1986; Samuels, Krugly-Smolska, \& Warren, 2001). In the present study, however, findings were only significant for boys. Furthermore, the present study used data from a large, international database, unlike these previous studies that based some of their findings on small samples, non-representative samples with limited generalizability.

The current study extends previous research in that it addresses obvious gaps in the literature. However, there were several limitations to the present study. First, a word of caution must be made about using plausible values to estimate students' performance on the PIRLS assessment, as this technique underestimates sampling error. As previously mentioned in chapter 3, the National Center for Education Statistics (NCES), in consultation with the International Association for the Evaluation of Educational Achievement (IEA), produced the IDB Analyzer to better estimate the sampling error. What is unknown, however, is whether such accommodations interfere with the accuracy of other analyses.

Another limitation was that although the overall sample was nationally representative, the numbers of foreign-born and second-generation immigrants was small, compared to the number of non-immigrants. Thus, several background and socioeconomic predictors were not included in the analysis due to questionable reliability of such measures (i.e., community type, school type, free-lunch eligibility, etc.), even though some of them may have been useful in the explanation of the educational outcomes included in the analysis.

Third, all data were based on student responses. The students in this sample were all fourth-graders, and it is difficult to assess whether these students were capable of 
accurately reporting family characteristics such as number of books in the home, length of U.S. residence, parents' educational attainment, and parents' country of origin. As a result, the researcher had to rely on the understandings of complicated, social ideas from very young students. For example, the number of students reporting that their parents were college graduates seemed to be inflated, especially when considering the percentage of college graduates nationwide.

Finally, this study was based on fourth-grade students. It is possible that, at such a young age, oppositional identities toward schooling have not yet been developed. For example, in international comparisons in math and science from the 2003 Trends in International Math and Science Survey (TIMSS), fourth-grade U.S. students perform comparatively well with other leading nations. However, by eighth-grade U.S. students begin to lag behind comparable countries such as Singapore, Hong Kong, Japan, and the Netherlands (Gonzales et al., 2004). This suggests that some factors within U.S. schools and society are having negative impacts on students nationwide, regardless of race, immigrant status, or socioeconomic status.

Despite these limitations, the present study contributes to a growing body of research on the educational experiences of Black immigrant and non-immigrant students in the United States and forms the basis for further investigation of academic performance of Black students. In addition, this study reveals insights into Black students' perceptions of literacy and schooling in the U.S. Further research should examine whether students' attitudes and performance vary across other subject areas. Another factor that should be examined more closely is ethnic identity. Racial categorization and ethnicity are not mutually exclusive terms; societal perceptions of race 
and ethnicity may actually contradict students' perceptions of themselves. Future research should also include longitudinal studies that follow groups of immigrant and non-immigrant Black students as they progress through their academic careers. Such longitudinal studies should investigate changes that may occur over time in factors that impact students' academic performance, attitudes and self-concept.

Finally, since much of Ogbu's research has informed educational policy, especially over the past two decades, it is important that educational researchers continue to produce evidence to inform policies and practices based on this work. As a direct test of Ogbu's theoretical arguments related to differences between Black non-immigrant and Black immigrant children's academic orientations and performance in the context of voluntary and involuntary minority status, the present study contributes to the body of evidenced-based knowledge related to Ogbu's work. Thus this study provides empirical evidence to inform policy-makers, school personnel and others in the larger community in planning effectively to meet academic needs of all children. 


\section{REFERENCES}

Alba, R., \& Nee, V. (1997). Rethinking assimilation: Theory for a new era of immigration. International Migration Review, 31, 826-874.

Ainsworth-Darnell, J., \& Downey, D. (1998). Assessing the oppositional culture explanation for racial/ethnic differences in school performance. American Sociological Review, 63, 536-553.

Ainsworth-Darnell, J., \& Downey, D. (2002). The search for oppositional culture among Black students. American Sociological Review, 67(1), 156-164.

Baker, D., Goesling, B., \& Letendre, G. ( 2002). Socioeconomic status, school quality and national economic development: A cross-national analysis of the "HeynemanLoxley Effect" on mathematics and science achievement. Comparative Education Review, 46(3), 291-312.

Bashi, V., \& McDaniel, A. (1997). A theory of immigration and racial stratification. Journal of Black Studies, 27, 668-682.

Bryce-Laporte, R. (1972). Black immigrants: The experience of invisibility and inequality. Journal of Black Studies, 3(1), 29-56.

Butcher, K. (1994). Black immigrants in the United States: A comparison with native Blacks and other immigrants. Industrial and Labor Relations Review, 47(2), 265284.

Desimone, L., Smith, T., Baker, D., \& Ueno, K. (2005). Assessing barriers to reform of U.S. mathematics instruction from an international perspective. American Educational Research Journal, 42, 501-535.

Dodoo, F. (1997). Assimilation differences among Africans in America. Social Forces, 76(2), 527-546.

Duncan , G., \& Magnuson, K. (2005). Can family socioeconomic resources account for racial and ethnic test score gaps? The Future of Children, 15(1), 35-54.

Farkas, G., Lleras, C., \& Maczuga, S. (2002). Does oppositional culture exist in minority and peer groups? American Sociological Review, 67(1), 148-155.

Fernandez, P. (2003). Academic orientations of African-American adolescents in MiamiDade County. Ph.D. dissertation, Florida International University, United States -Florida. Retrieved February 28, 2008, from ProQuest Digital Dissertations database. (UMI No. 3065812). 
Fisher, E. (2005). Black student achievement and the oppositional culture model. The Journal of Negro Education, 74(3), 201-209.

Foner, N. (Ed.). (1987). New immigrants in New York. New York: Columbia University Press.

Ford, D., \& Harris, J. (1996). Perceptions and attitudes of Black students toward school, achievement, and other educational variables. Child Development, 67, 1141-1152.

Gibson, M. (1991). Ethnicity, gender and social class: The school adaptation patterns of West Indian youths. In M. Gibson \& J. Ogbu (Eds.), Minority status and schooling: A comparative study of immigrant and involuntary minorities (pp. 169203). New York: Garland.

Gibson, M., \& Ogbu, J. (Eds.). (1991). Minority status and schooling: A comparative study of immigrant and involuntary minorities. New York: Garland.

Glick, J.E. (2004). Country of origin and ethnicity as predictors of educational outcomes for children in immigrant families. Proceedings of the August 2004 meeting of the American Sociological Association. Washington, DC: American Sociological Association.

Gonzales, P., Guzmán, J. C., Partelow, L., Pahlke, E., Jocelyn, L., Kastberg, D., \& Williams, T. (2004). Highlights from the Trends in International Mathematics and Science Study (TIMSS) 2003 (NCES 2005-005). U.S. Department of Education, National Center for Education Statistics. Washington, DC: U.S. Government Printing Office.

Gordon, M. (1964). Assimilation in American life. New York: Oxford University Press.

Harris, A. (2006). I (don't) hate school: Revisiting oppositional culture theory of Blacks' resistance to schooling. Social Forces, 85(2), 797-834.

Haycock, K., \& Navarro, M. (1988). Unfinished business: Fulfilling our children's promise. Oakland, California: The Achievement Council. (ERIC Document Reproduction Service No. ED299025)

Henke, H. (2001). The West Indian Americans. Westport, CT: Greenwood Press.

Hochschild, J. (1995). Facing up to the American dream: Race, class, and the soul of the nation. Princeton, NJ: Princeton University Press.

Jensen, A. (1969). How much can we boost IQ and scholastic achievement? Harvard Educational Review, 39, 1-123. 
Kao, G., \& Thompson, J. (2003). Racial and ethnic stratification in educational achievement and attainment. Annual Review of Sociology, 29, 417-442.

Kao, G., \& Tienda, M. (1995). Optimism and achievement: The educational performance of immigrant youth. Social Science Quarterly, 76(1), 1-19.

Kasinitz, P. (1992). Caribbean New York: Black immigrants and the politics of race. Ithaca, NY: Cornell University Press.

Kastberg, D., Roey, S., Williams, T., Smith, C., Baldi, S., \& Ogle, L. (2004). The Progress in International Reading Literacy Study (PIRLS) 2001 United States user's guide (NCES 2004-016). U.S. Department of Education, National Center for Education Statistics, Institute for Education Sciences. Washington, DC: U.S. Government Printing Office.

KewalRamani, A.; Gilbertson, L; Fox, M.; \& Provasnik, S. (2007). Status and trends in the education of racial and ethnic minorities (NCES 2007-039). U.S. Department of Education, National Center for Education Statistics, Institute for Education Sciences. Washington, DC: U.S. Government Printing Office.

Levitt, S., \& Fryer, R. (2004). Falling Down: New evidence on the Black-White achievement gap. Education Next, 4(4), 64-71.

Marks, G., McMillan, J., Jones, F., \& Ainley, J. (2000). The Measurement of Socioeconomic Status for the Reporting of Nationally Comparable Outcomes of Schooling. Camberwell, VIC, Australia: Australian Council for Educational Research \& Sociology Program Research, School of Social Sciences, Australian National University.

Martin, M., Mullis, I., \& Kennedy, A. (2003). PIRLS 2001 technical report. Boston: International Study Center, Lynch School of Education, Boston College.

Massey, D., Mooney, M., Torres, K., \& Charles, C. (2007). Black immigrants and Black natives attending selective colleges and universities in the United States. American Journal of Education, 113, 243-271.

McWhorter, J. (2000). Losing the race: Self-sabotage in Black America. New York: Free Press.

Mickelson, R. (1990). The attitude-achievement paradox among Black adolescents. Sociology of Education, 63(1), 44-61.

Ogbu, J. (1978). Minority education and caste: The American system in cross-cultural perspective. New York: Academic Press. 
Ogbu, J. (1990). Minority education in comparative perspective. Journal of Negro Education, 59, 45-57.

Ogbu, J. (1991). Immigrant and involuntary minorities in perspective. In M. Gibson \& J. Ogbu (Eds.), Minority status and schooling: A comparative study of immigrant and involuntary minorities, pp. 3-33. New York: Garland.

Ogbu, J. (2003). Black American students in an affluent suburb: A study of academic disengagement. Mahwah, NJ: Lawrence Erlbaum Associates.

Ogbu, J., \& Simons, H. (1994). Cultural models of literacy: A Comparative study: Cultural models of school achievement: A quantitative test of Ogbu's theory (Report No. CS214649). Berkeley, CA: National Center for the Study of Writing and Literacy. (ERIC Document Reproduction Service NO. ED376515)

Ogbu, J., \& Simons, H. (1998). Voluntary and involuntary minorities: A culturalecological theory of school performance with some implications for education. Anthropology \& Education Quarterly, 29(2), 155-188.

Ogle, L., Sen, A., Pahlke, E., Jocelyn, L., Kastberg, D., Roey, S., \& Williams, T. (2003). International comparisons in fourth-grade reading literacy: Findings from the Progress in International Reading Literacy Study (PIRLS) 2001 (NCES 2003073R). U.S. Department of Education, Institute of Education Sciences. Washington, DC: U.S. Government Printing Office.

Omi, M., \& Winant, H. (1986). Racial formation in the United States from the 1960 s to the 1980s. New York: Routledge.

Park, R., \& Burgess, E. (1969). Introduction to the science of sociology (reprint). Chicago: University of Chicago Press.

Perreira, K., Harris, K., \& Lee, D. (2006). Making it in America: High school completion by immigrant and native youth. Demography, 43, 511-536.

Portes, A., \& Rumbaut, R. (1990). Immigrant America: A portrait. Berkeley, CA: University of California Press.

Portes, A., \& Rumbaut, R. (2001). Legacies: The story of the immigrant second generation. Berkeley, CA: University of California Press.

Portes, A., \& Stepick, A. (1993). City on the edge. Berkeley, CA: University of California Press. 
Portes, A., \& Zhou, M. (1993). The new second generation: Segmented assimilation and its variants. Annals of the American Association of Political and Social Sciences, 530, 74-96.

Rong, X., \& Brown, F. (2001). The effects of immigrant generation and ethnicity on educational attainment among young African and Caribbean Blacks in the United States. Harvard Educational Review 71, 536-565.

Rong, X., \& Brown, F. (2002). Socialization, culture, and identities of Black immigrant children: What educators need to know and do. Education and Urban Society, $34(2), 247-273$.

Rong, X., \& Preissle, J. (1998). Educating immigrant students: What we need to know to meet the challenge. Thousand Oaks, CA: Corwin Press.

Roscigno, V., \& Ainsworth-Darnell, J. (1999). Race, cultural capital, and educational resources: Persistent inequalities and achievement returns. Sociology of Education, 72, 158-178.

Rumbaut, R. (1994). The crucible within: Ethnic identity, self-esteem, and segmented assimilation among children of immigrants. International Migration Review, 28, 748-794.

Samuels, E., Krugly-Smolska, E., \& Warren, W. (2001). Academic achievement of adolescents from selected ethnocultural groups in Canada: A study consistent with John Ogbu's theory. McGill Journal of Education, 36(1), 61-73.

Sewell, T. (1981). Ethnic America: A history. New York: Basic Books.

Slade, M. (1982, October 24). Aptitude, intelligence or what? New York Times, pp.2223.

Smith, J., Brooks-Gunn, J., \& Klebanov, P. (1997). The consequences of living in poverty on young children's cognitive development. In G. Duncan \& J. BrooksGunn (Eds.), Consequences of growing up poor, pp. 132-189. New York: Russell Sage.

Soloranzo, D., \& Yosso, T. (2001). From racial stereotyping and deficit discourse: Toward a critical race theory in teacher education. Multicultural Education, 9(1), 2-8.

Stepick, A. (1995). The academic orientation of minority adolescents. Unpublished manuscript. 
Suarez-Orozco, M. (1991). Immigrant adaptation to schooling: A Hispanic case. In M. Gibson \& J. Ogbu (Eds.), Minority status and schooling: A comparative study of immigrant and involuntary minorities, pp. 37-61. New York: Garland.

Tremblay, S., Ross, N., \& Berthelot, J. (2001). Factors affecting grade 3 student performance in Ontario: A multilevel analysis. Education Quarterly Review, 4(7), 25-36.

Tyson, K. (2002). Weighing in: Elementary-age students and the debate on attitudes toward school among Black students. Social Forces, 80, 1157-1189.

U.S. Department of Commerce, Census Bureau. (2001). Overview of race and Hispanic origin. Washington, DC: U.S. Government Printing Office.

U.S. Department of Commerce, Census Bureau. (2004). Statistical abstract of the United States: 2004-2005 (124 ed.). Washington, DC: Author.

U.S. Department of Commerce, Census Bureau, American Community Survey. (2005). Population estimates program, foreign-born resident population estimates and native population estimates of the United States by sex, race and Hispanic origin. Washington, DC: Author.

Van den Berghe, P. (1980). A review of minority education and caste: The American system in cross-cultural perspective. Comparative Education Review, 24(1), 126130.

Waters, M. (1991). The role of lineage in identity formation among Black Americans. Qualitative Sociology, 14, 57-76.

Waters, M. (1994). Ethnic and racial identities of second-generation Black immigrants in New York City. International Migration Review, 28, 795-821.

Waters, M. (1999). Black identities: West Indian immigrant dreams and American realities. New York: Russell Sage Foundation.

Wiggan, G. (2007). Race, school achievement, and educational inequality: Toward a student-based inquiry perspective. Review of Educational Research, 77(3), 310333.

Wilson, W. (1980). Race, class and public policy in education. Lecture presented at the National Institute of Education, Vera Brown Memorial Seminar Series, Washington, DC.

Woldemikael, T. (1989). Becoming Black American: Haitian and American institutions in Evanston, Illinois. New York: AMS. 
APPENDIX A

SYNOPSIS OF REVIEWED LITERATURE 


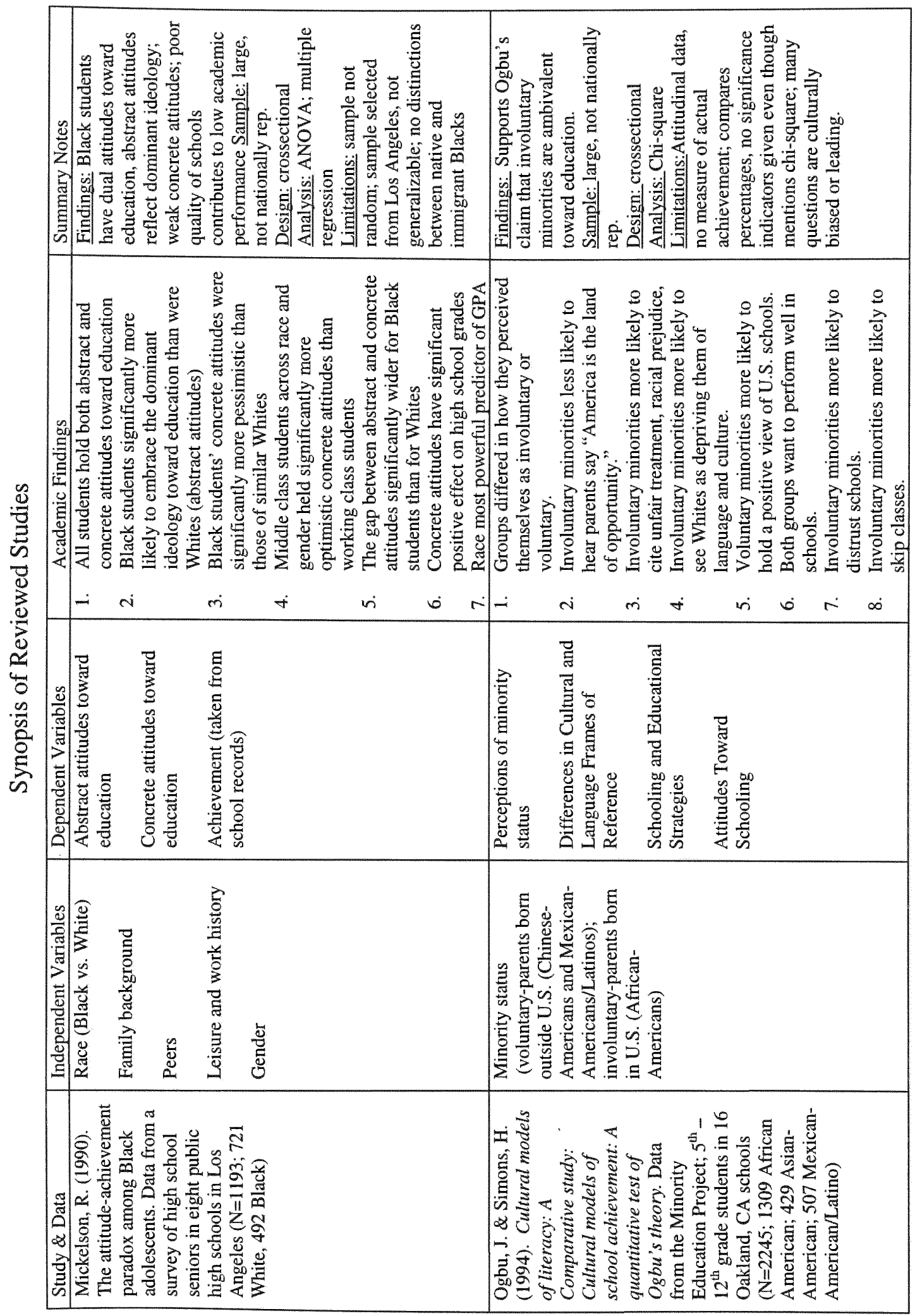




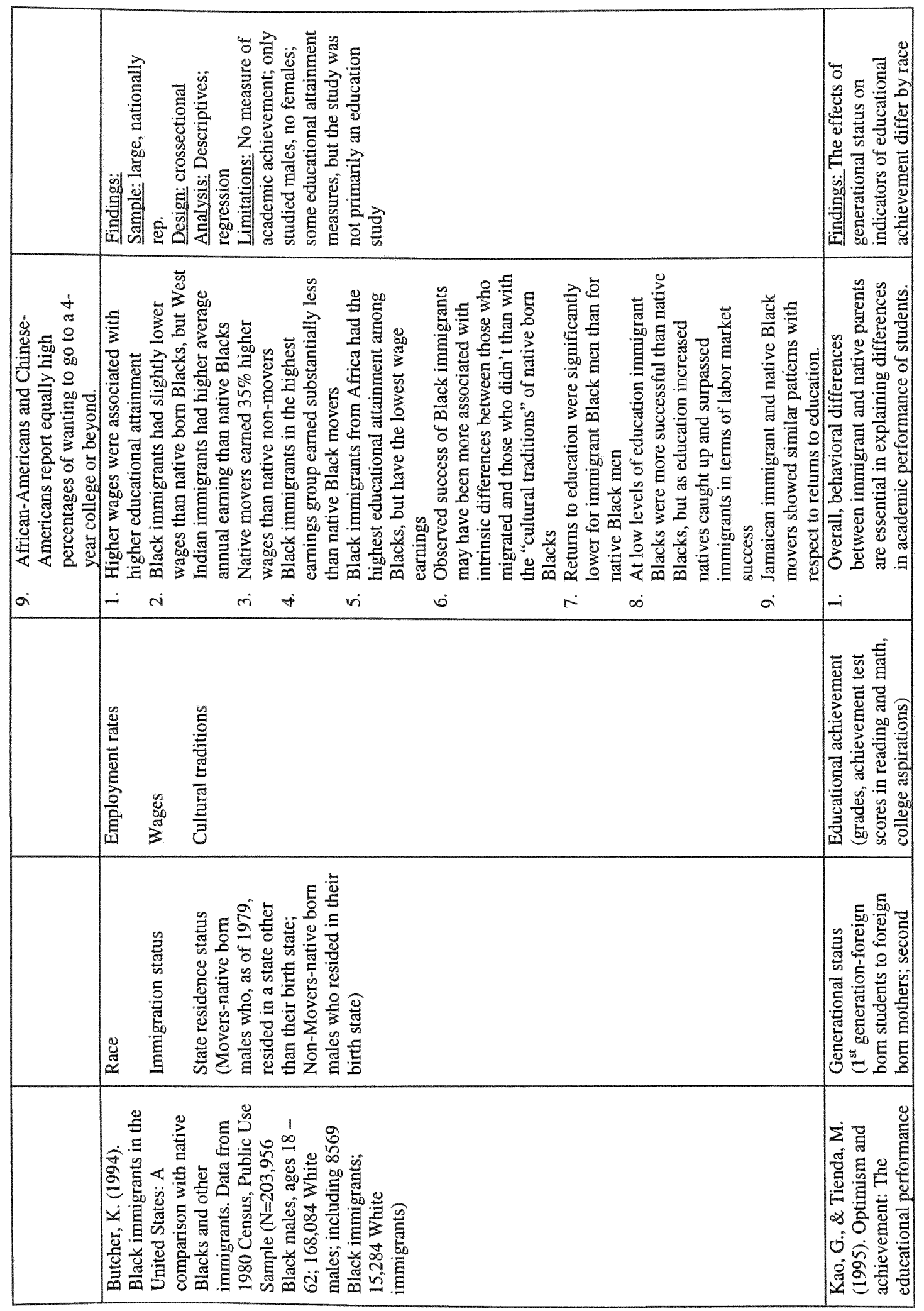




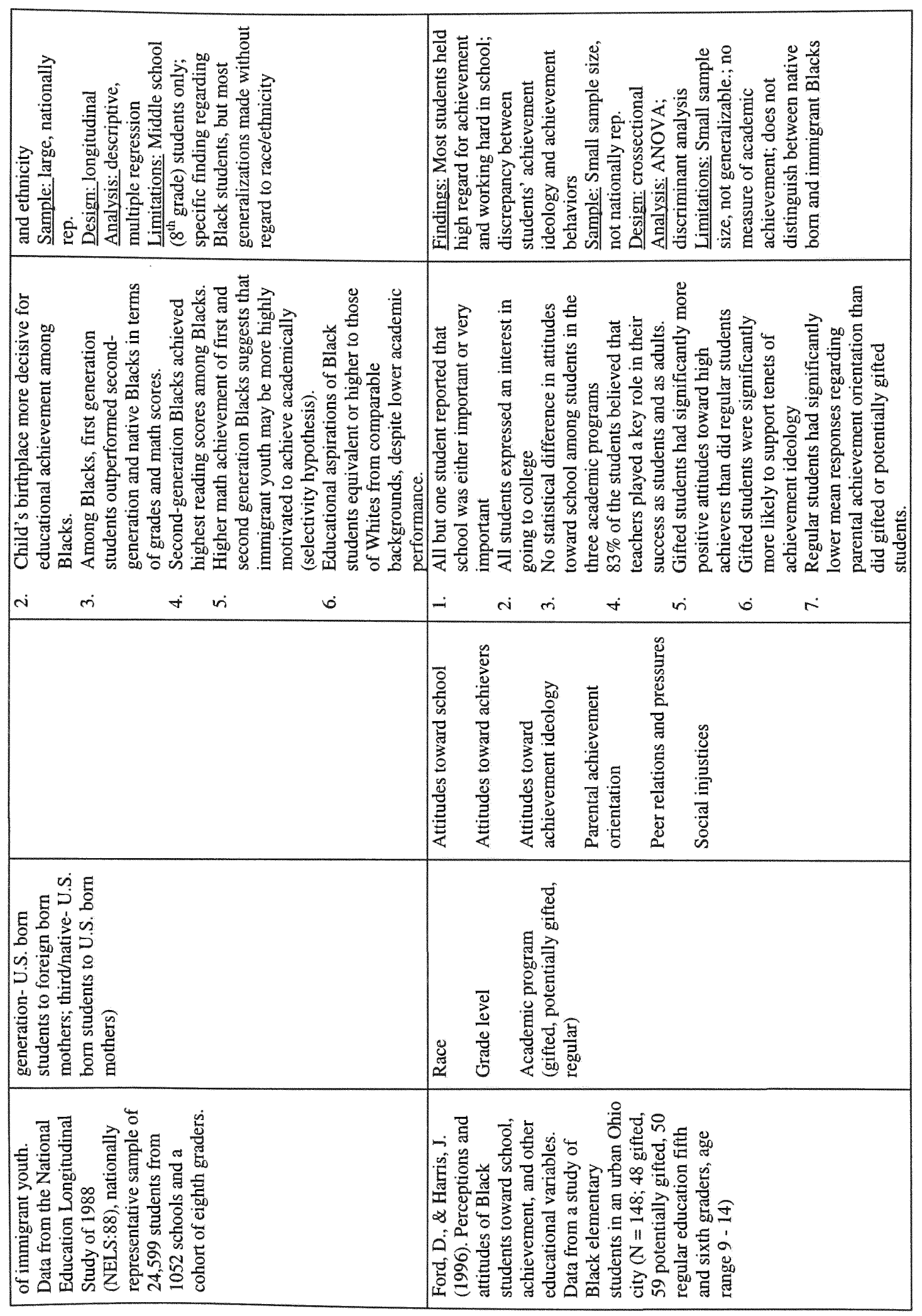




\begin{tabular}{|c|c|c|}
\hline & 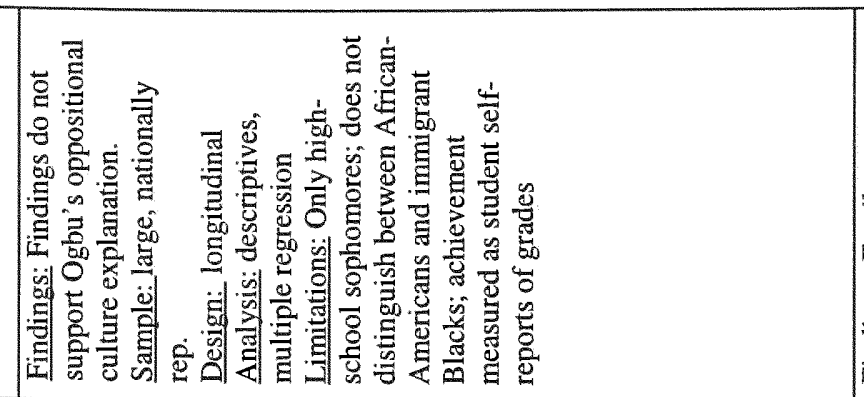 & 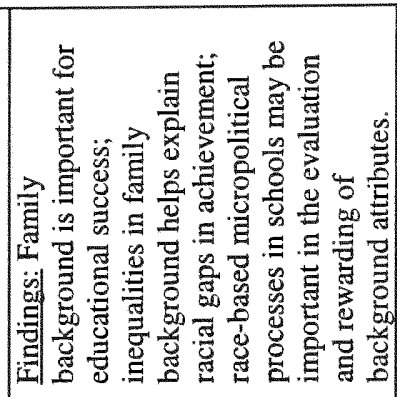 \\
\hline 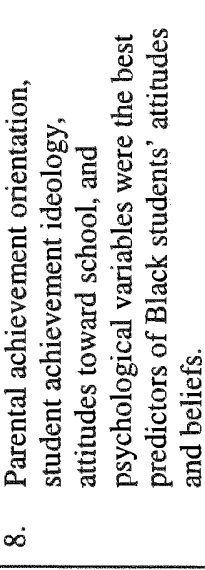 & 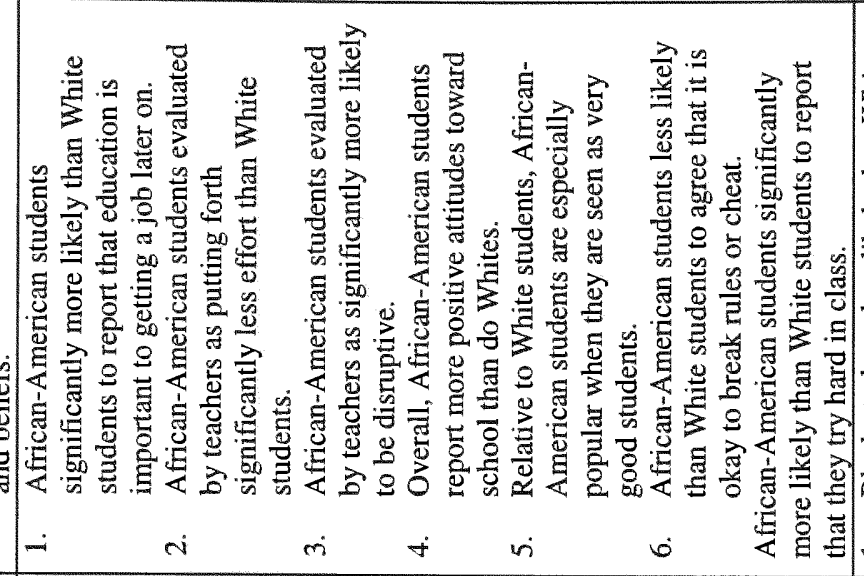 & 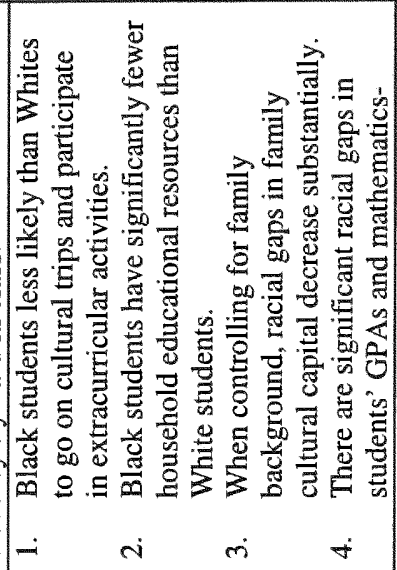 \\
\hline & 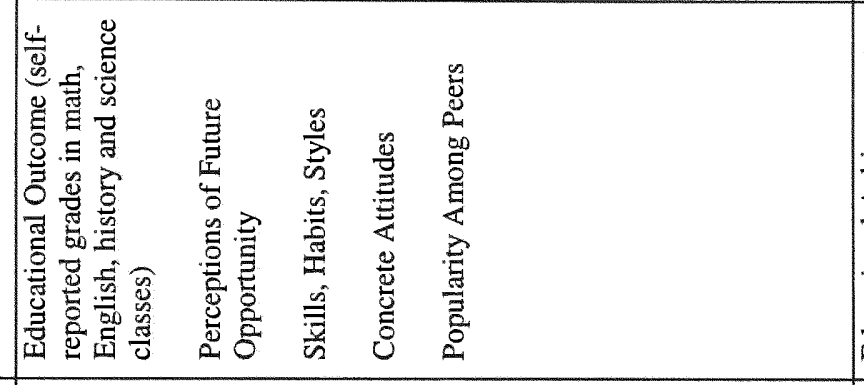 & 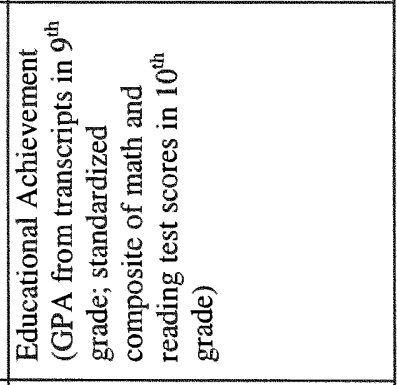 \\
\hline & 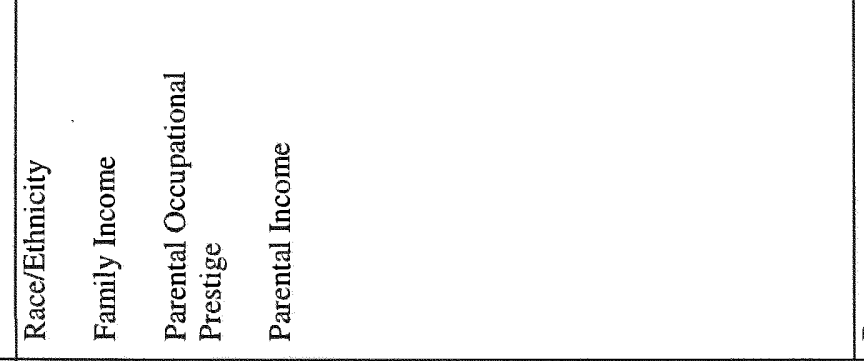 & 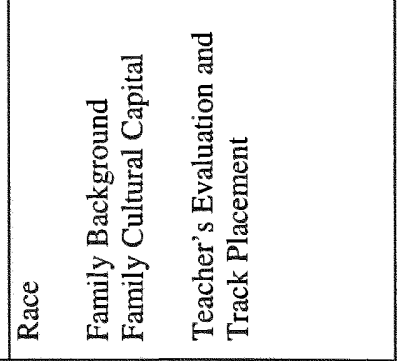 \\
\hline & 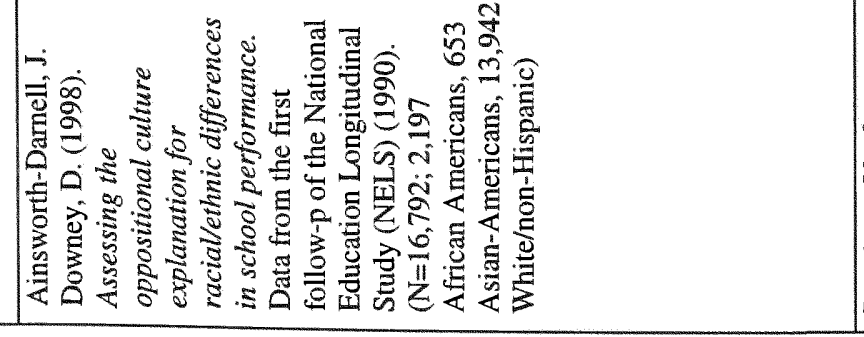 & 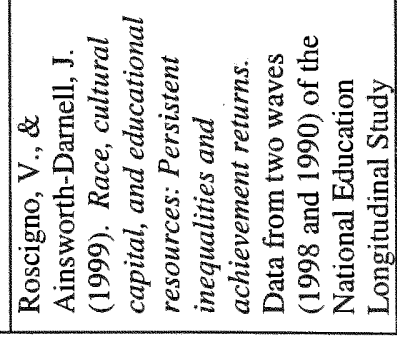 \\
\hline
\end{tabular}




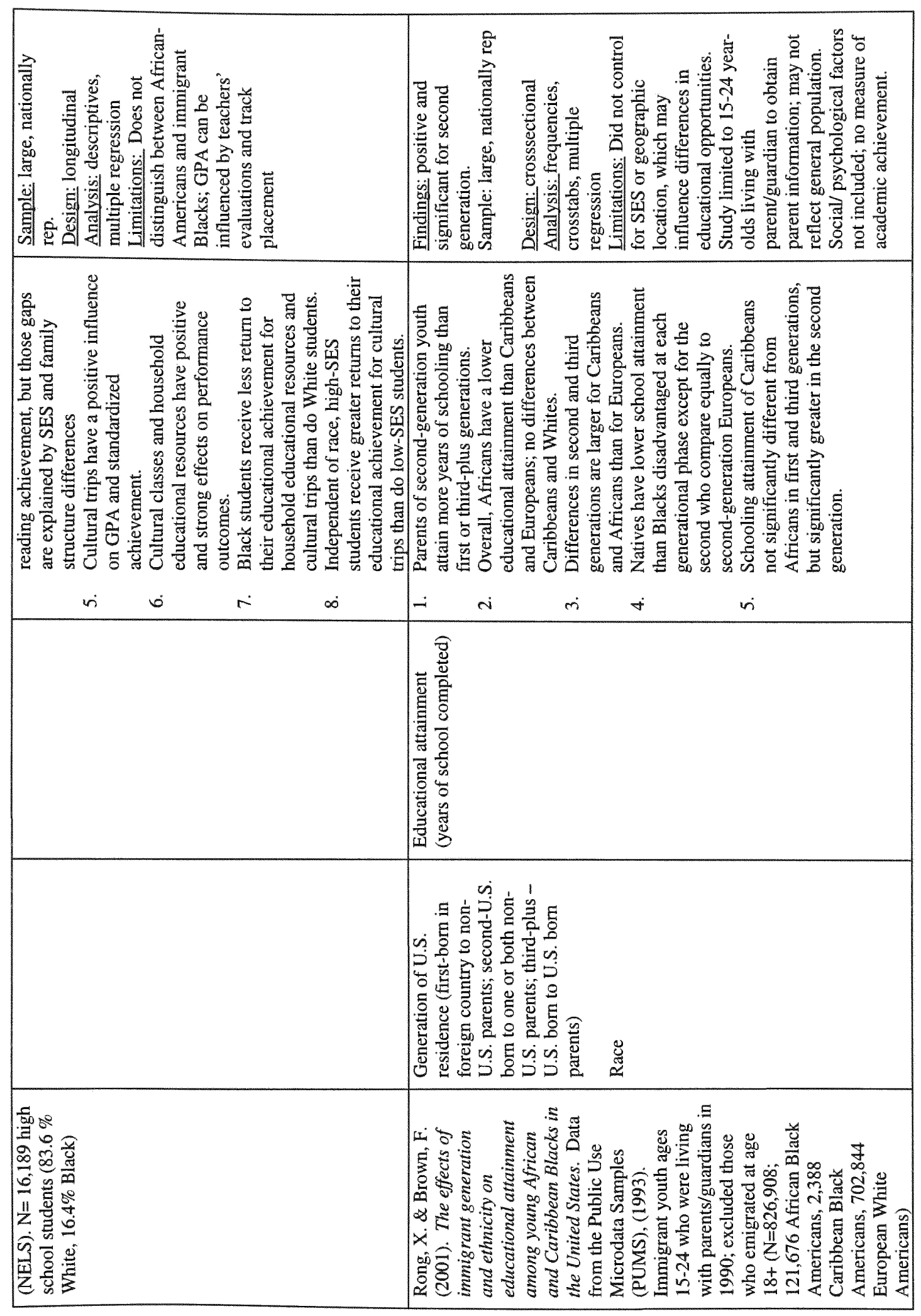




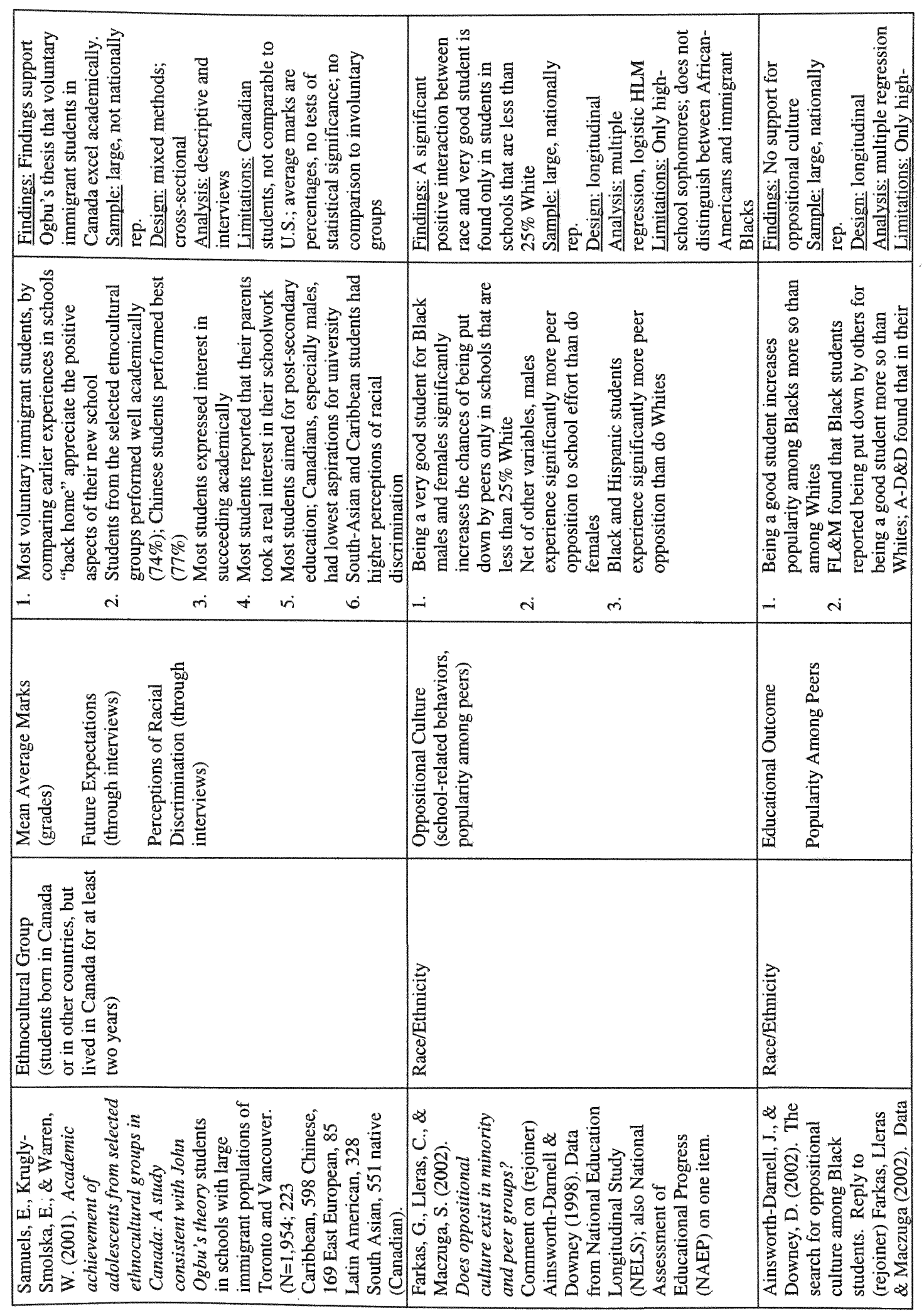

$\alpha$ 


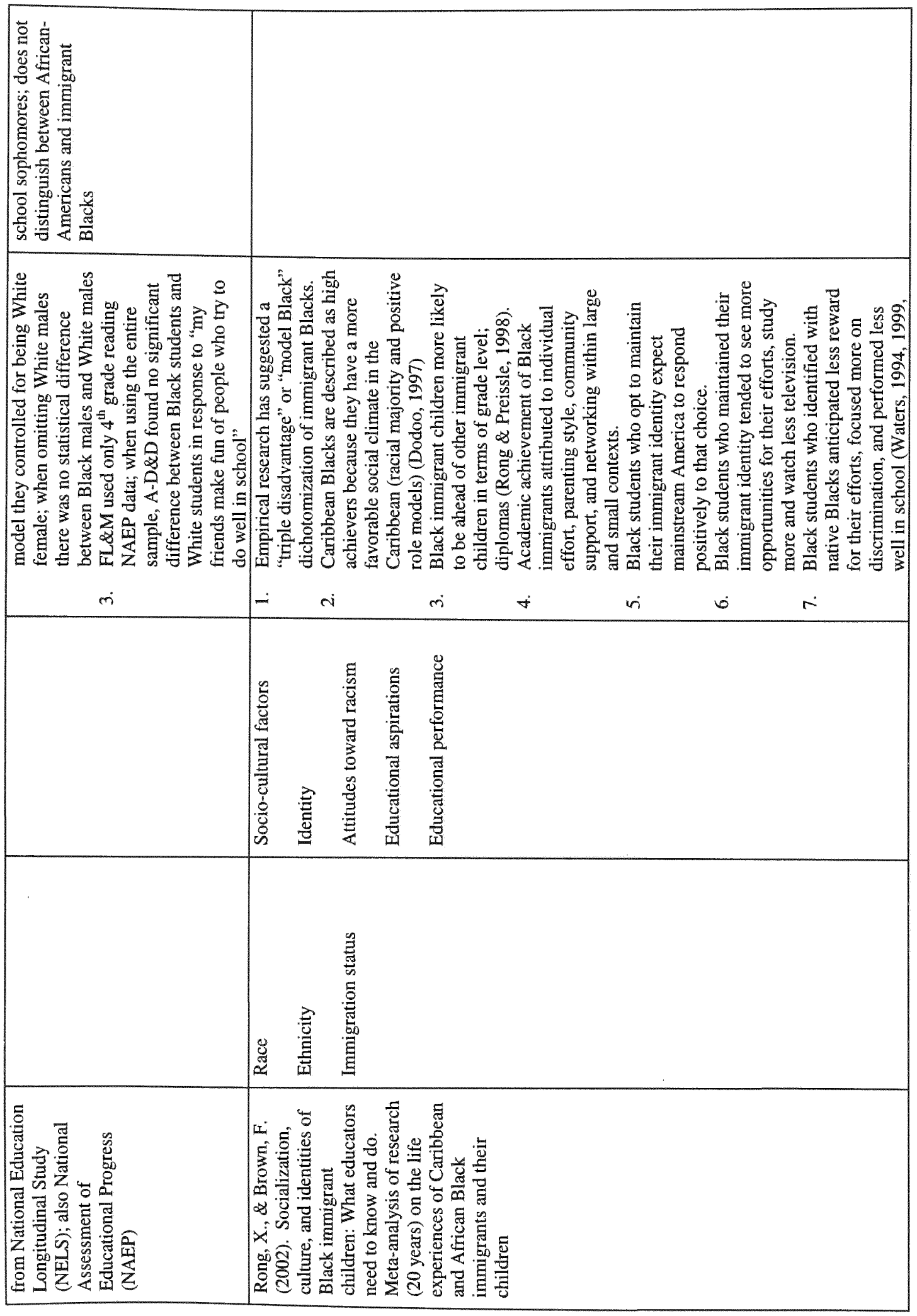

$\sigma$ 


\begin{tabular}{|c|c|c|}
\hline & 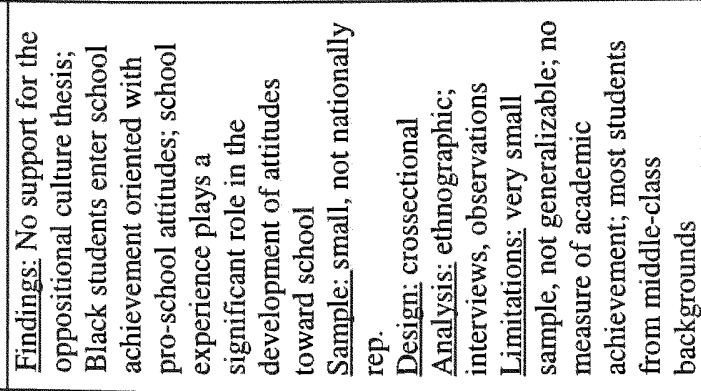 & 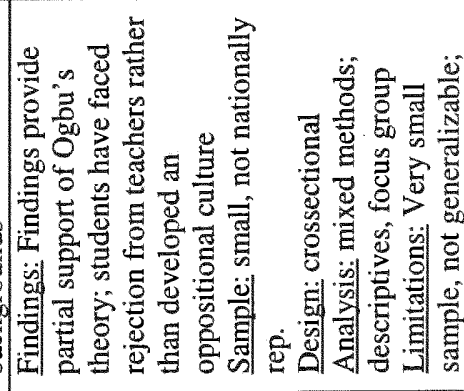 \\
\hline 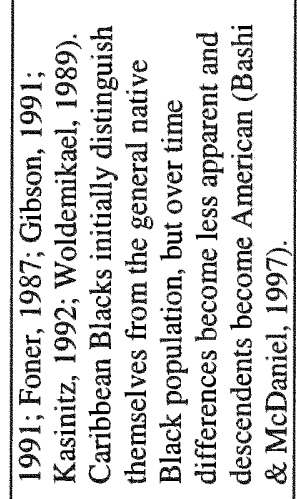 & 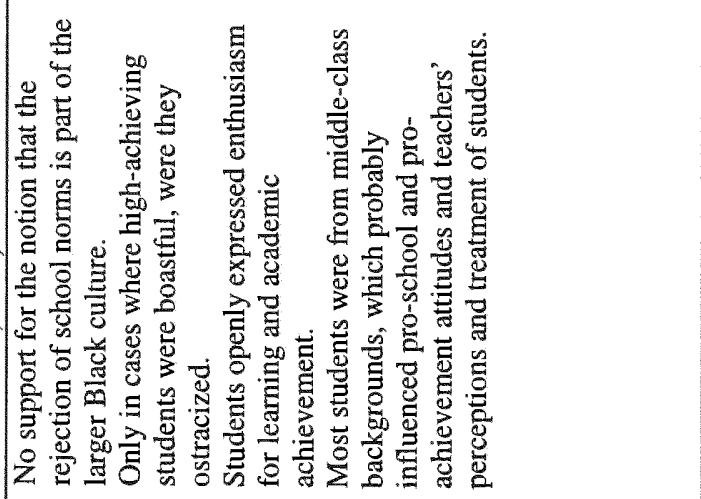 & 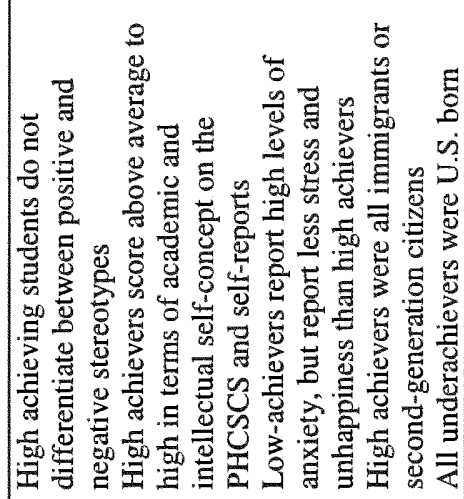 \\
\hline$\infty$ & i $\quad \dot{r}$ & $\therefore \quad \infty \quad \dot{0}$ \\
\hline & 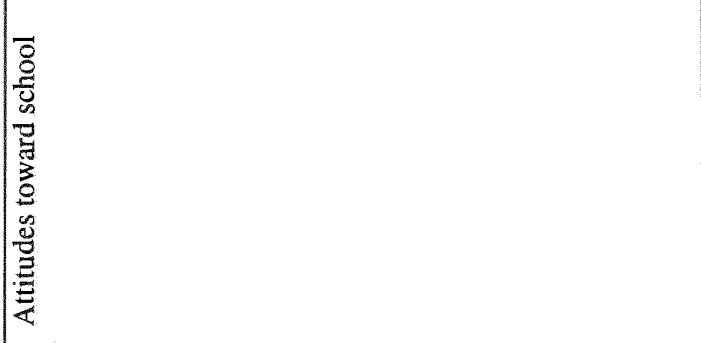 & 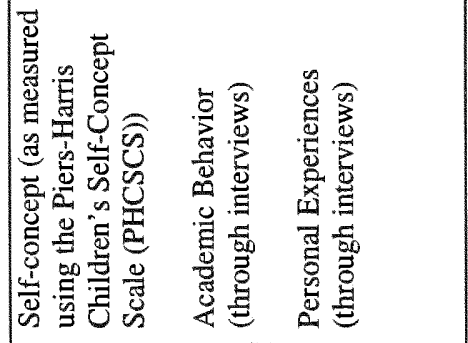 \\
\hline & 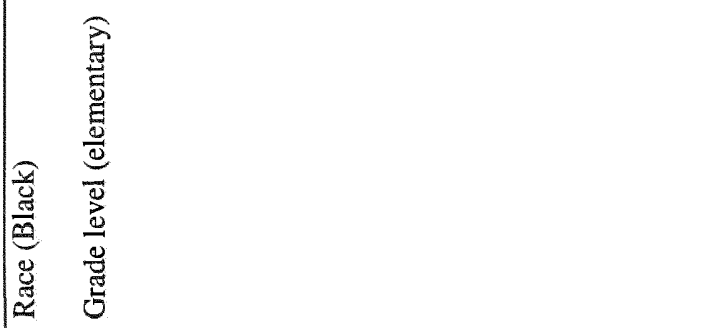 & 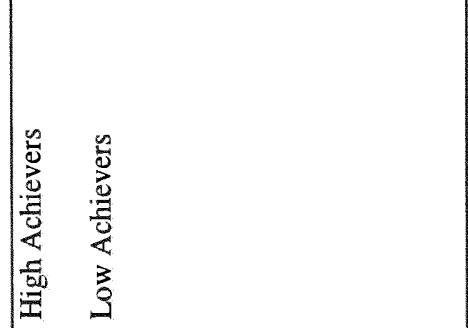 \\
\hline & 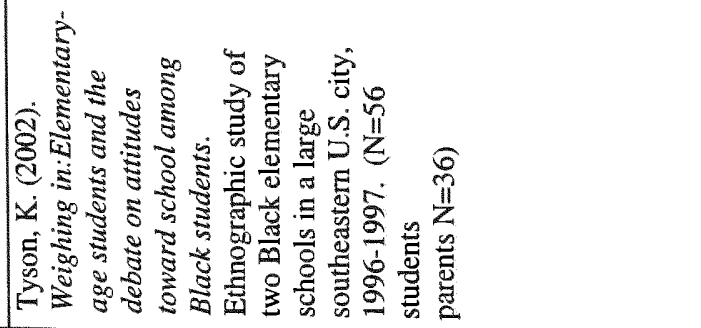 & 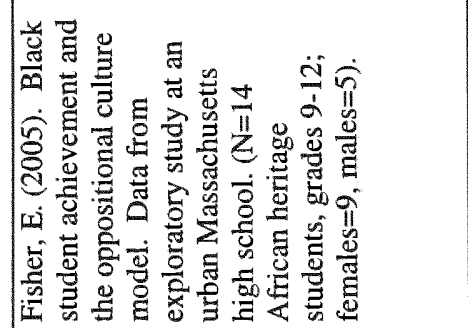 \\
\hline
\end{tabular}




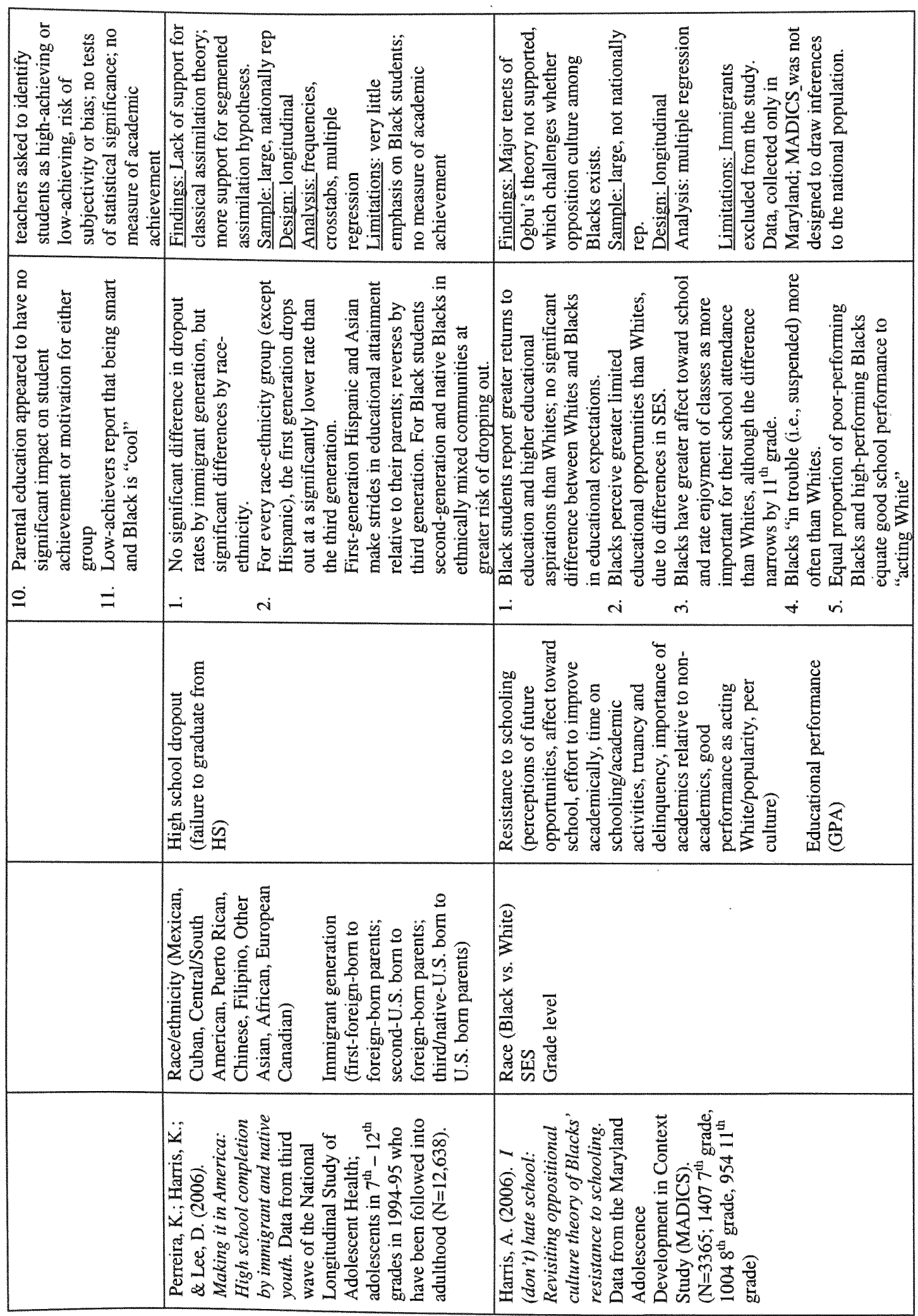




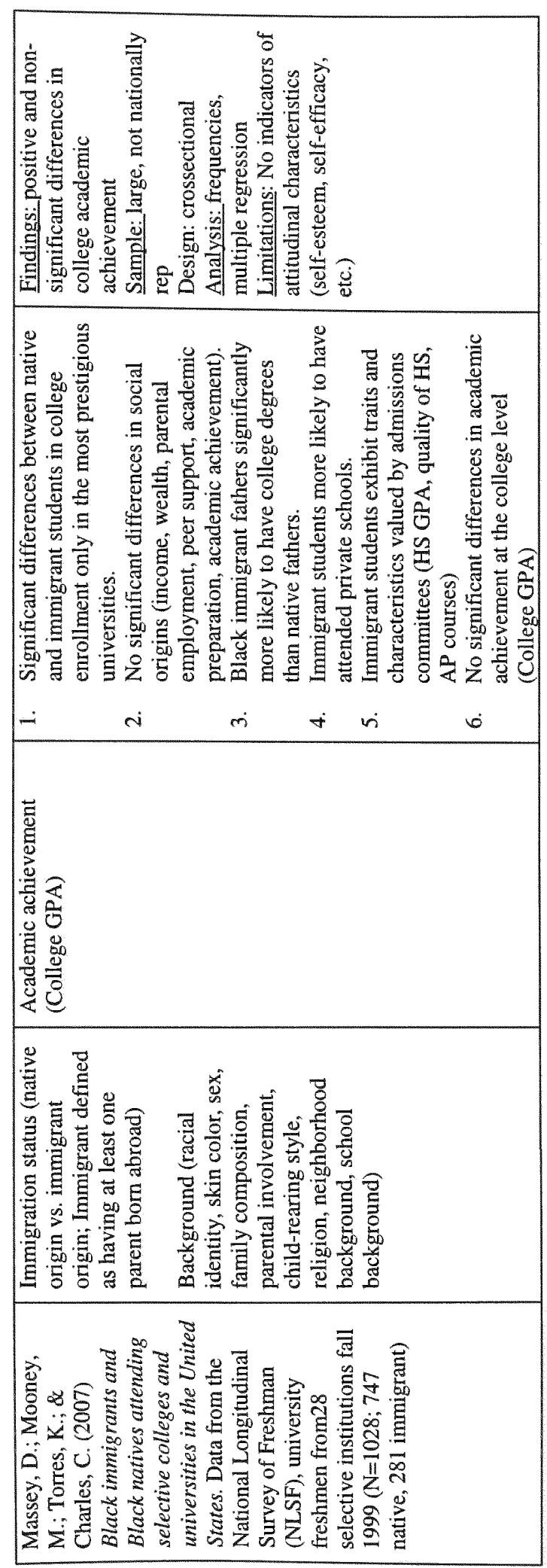

๙ 


\section{APPENDIX B}

PROGRESS IN INTERNATIONAL READING LITERACY STUDY (PIRLS 2001)

SAMPLE TEST ITEM 


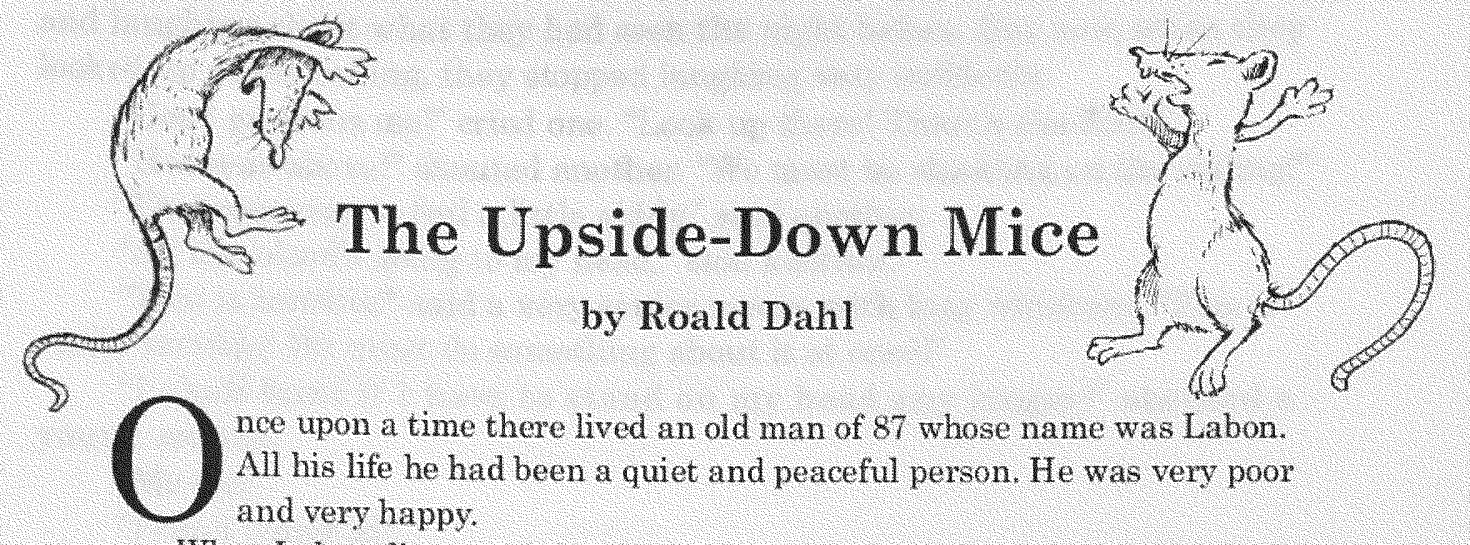

When Labon discovered that he had mice in his house, it did not bother him much at first. But the mice multiplied. They began to bother him. They kept on multiplying and finally there came a time when even he could stand it no longer.

"This is too much," he said. "This really is going a bit too far:" He hobbled out of the house down the road to a shop where he bought some mousetraps, a piece of cheese and some glue.

When he got home, he put the glue on the underneath of the mousetraps and stuck them to the ceiling. Then he baited them carefully with pieces of cheese and set them to go off:

That night when the mice came out of their holes and saw the mousetraps on the ceiling, they thought it was a tremendous joke. They walked around on the floor, nudging each other and pointing up with their front paws and roaring with laughter. After all, it was pretty silly, mousetraps on the ceiling.

When Labon came down the next morning and saw that there were no mice caught in the traps, he smiled but said nothing.

He took a chair and put glue on the bottom of its legs and stuck it upside-down to the ceiling, near the mousetraps. He did the same with the table, the television set and the lamp. He took everything that was on the floor and stuck it upside-down on the ceiling. He even put a little carpet up there.

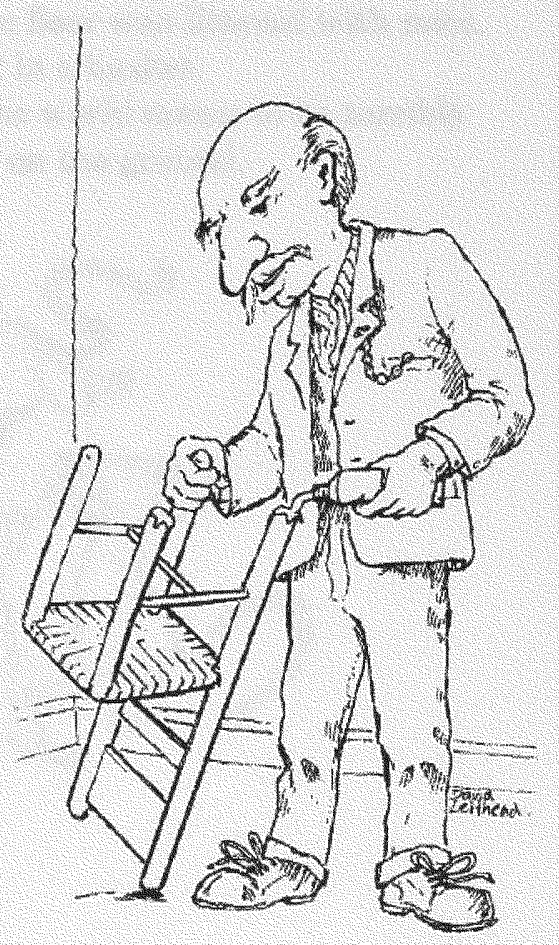


The noxt night when the mice came out of their holes they were still joking and laughing about what they had seen the night before. But now, when they looked up at the ceiling, they stopped laughing very suddenly.

"Good gracious mel" cried one. "Look up there! There's the floor:"

"Heavens above"." shouted another, "We must be standing on the ceiling!"

"I'm beginning to feel a little giddy." said another.

"All the blood's going to my head," said another.

"This is terrible!" said a very senior mouse with long whiskers. "This is really temible! We must do something about it at oncel"

"I shall faint if 1 have to stand on my head any longer"" shouted a young nouse.

"Me too"

"I can't stand it:"

"Save us! Do something somebody, quick"'

They were getting hysterical now. "I know what well do," said the very senior mouse, "Woll all stand on cur heads, then well be the right way up."

Obediently, they all stood on their heads, and after a long time, one by one they fainted from a rush of blood to their brains.

When Labon came down the next moming the foor was littered with mice. Quickly he gathered them up and popped them all in a basket.

So the thing to remember is this: whenever the world seems to be terribly upside-down, make sure you keep your feet frmly on the ground.

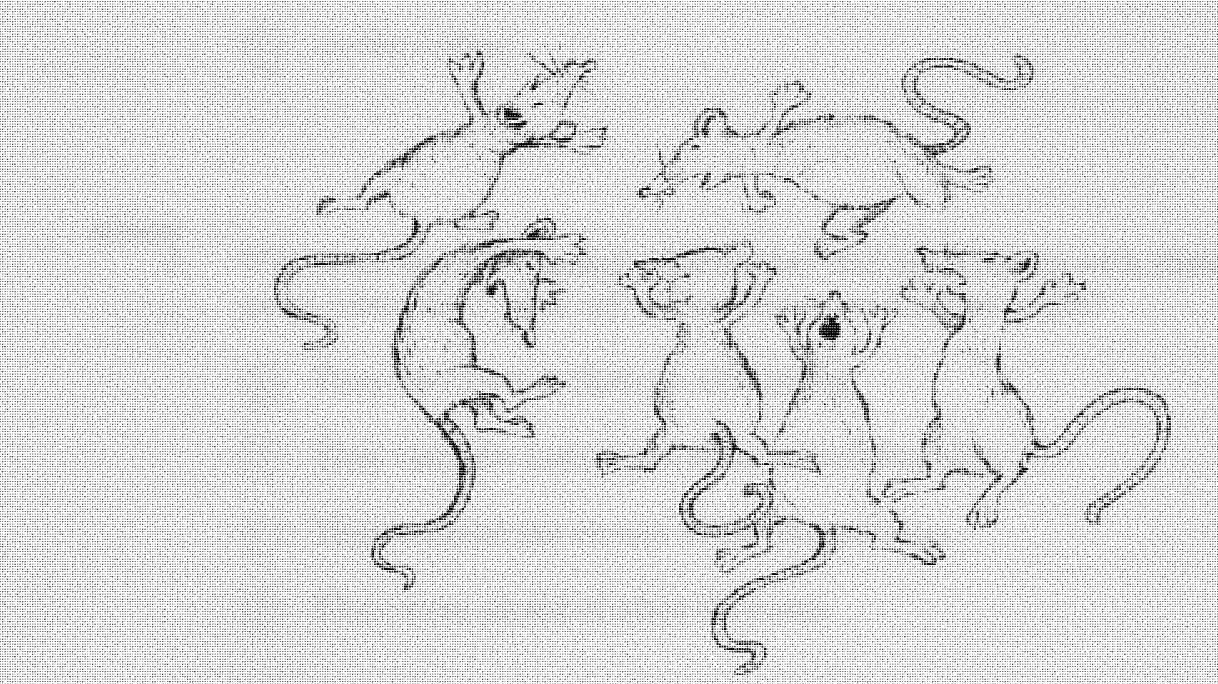




\section{Questions The Upside-Down Mice}

1. Why did Labon want to get rid of the mice?

A He had always hated mice.

(3) There were too many of them.

c. They laughed too loudly.

(1) They ate all his cheese.

2. Where did Labon put the mousetraps?

a in a basket

B near the mouse holes

(6) under the chairs

(1) on the ceiling

3. Why were the mice nudging each other and pointing up with their paws when they came out of their holes on the first night?

A) They could see a chair on the ceiling.

B They thought Labon had done something silly.

c) They wanted the cheese in the mousetraps.

(b) They were afraid of what they saw. 
4. Why did Labon smile when he saw there were no mice in the traps?

(1)

5. What did Labon do after he stuck the chair to the ceiling?

A smiled and said nothing

(3) bought some mousetraps

(c) stuck everything to the ceiling

b. gave the mice some cheese

6. On the second night, where did the mice think they were standing and what did they decide to do about it?

Where the mice thought they were standing:

2 
7. Find and copy one of the sentences that show the panic the mice felt on the second night.

8. How does the story show you what the mice thought was happening?
(A) by telling you what Labon thought of the mice
(B) by describing where the mice lived
C by telling you what the mice said to one another
(D) by describing what the mice were like

9. Why was the floor covered with mice when Labon came down on the last morning?

The mice had stood on their heads for too long.

(3) Labon had given the mice too much cheese.

(6) The mice had fallen from the ceiling.

(b) Labon had put glue on the floor. 
10. Where did Labon put the mice when he picked them up from the floor?

(2)

11. Do you think the mice were easy to fool? Give one reason why or why not.

(4)

12. You learn what Labon is like from the things he does. Describe what he is like and give two examples of what he does that show this.

38

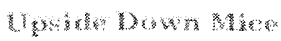


13. Which words best describe this story?

A serious and sad

B scary and exciting

conny and clever

b) thrilling and mysterious

14. Think about what Labon and the mice did in the story. Explain what makes the story unbelievable.

(1)

End of this part of the booklet.

Please stop working. 


\section{VITA}

\section{SHELBY G. GILBERT}

1996

B.S., Communication

University of Miami

Coral Gables, Florida

1999

M.S.Ed., Higher Education Leadership

University of Miami

Coral Gables, Florida

\section{ACADEMIC HONORS/ AWARDS}

2007

Dissertation Year Fellowship, Florida International University

1999

Award of Academic Merit, University of Miami

TEACHING EXPERIENCE

2007

Adjunct Instructor

University of Miami

Coral Gables, Florida

2004-2008

Adjunct Instructor

Florida International University

Miami, Florida

\section{OTHER ACADEMIC EXPERIENCE}

2005-2006

Graduate Research Assistant, Statistical Consulting

Florida International University

Miami, Florida

2002-2006

Program Coordinator, The Academy for the Art of Teaching

Florida International University

Miami, Florida

\section{SCHOLARLY PUBLICATIONS AND PRESENTATIONS}

Gilbert, S. (2008). Nativity Status, Educational Orientation, and the Academic Achievement of Black Students in the U.S. Presented at the annual conference of the Southern Sociological Society, April 9-12, 2008, Richmond, Virginia. 
Gilbert, S. (2008). Language, Political Economy and Power in Eco-Justice Discourse. Presented at the American Educational Research Association Annual Meeting, March 24-28, 2008, New York, New York.

Gilbert, S. (2007). Curriculum. In W.A. Darity, Jr. (Ed.), International Encyclopedia of the Social Sciences, 2nd edition (Vol. 2, pp. 213-215). Detroit: Macmillan Reference USA.

Gilbert, S. (2007). Schooling. In W.A. Darity, Jr. (Ed.), International Encyclopedia of the Social Sciences, $2^{\text {nd }}$ edition (Vol. 7, pp. 350-352). Detroit: Macmillan Reference USA.

Gilbert, S. \& Dawkins, M. (2007). The Impact of Voluntary-Involuntary Minority Status on the Educational Orientation and Achievement of Black Children. Presented at the American Educational Research Association Annual Meeting, April 9-13, 2007, Chicago, Illinois.

Gilbert, S. (2007). A Comparison of Educational Orientation and Academic Achievement Between Voluntary and Involuntary Black Students in the U.S. Presented at the Annual Meeting of the Comparative and International Education Society, February 25-March 1, 2007, Baltimore, Maryland.

Gilbert, S. (2006). An analysis of academic achievement between West-Indian and African-American students in South Florida. Presented at the $50^{\text {th }}$ Annual Meeting of the Comparative and International Education Society, March 14-18, 2006, Honolulu, Hawaii.

Gilbert, S. (2005). Academic achievement and ethnic identity in West-Indian and African-American students. Presented at the Second Annual International Conference on Social Science Research, December 4-6, 2005, Orlando, Florida.

Gilbert, S. (2005). A comparative analysis of academic achievement between West-Indian and African-American students in the southeastern U.S. Presented at the $68^{\text {th }}$ Annual Meeting of the Southern Sociological Society, April 13-16, 2005, Charlotte, North Carolina.

Banya, K. \& Gilbert, S. (2004). Diversity and the canon debate: Some reflections. Florida International University Diversity Exchange, Fall 2004, 26-27.

Gilbert, S. (2003). Language, environmental discourse and power: Barriers to ecojustice? Presented at the National Eco-Justice and Teacher Education Conference, February 28, 2003, Coral Gables, Florida. 